\title{
4 German Economic Activities in the Province of Tripoli and Ottoman-German Relations in 1910
}

German-Italian economic interests in the Province of Tripoli faced both German and Italian activities and ambitions in the province. Italian reaction faced privileges provided to some Germans in Tripoli directly from the Ottoman government. This is discussed in German archives based mainly on some statistics on trade activity between them, trade exchange and the different stages of its development from the establishment of a direct shipping line in $1889^{1}$ gathered by Banks, the director of the company from $1906^{2}$ to 1918.

Before World War I, different phases of the relations depended on the rule of different Ottoman Sultans and the German Emperor. 1880 was the starting point of official German-Ottoman relations after German unification, which continued even during the deterioration of the Ottoman Empire. During this time, Germany supported the Ottoman Empire and relations strengthened until the heralding of a new relationship with Italy with the announcement of German neutrality during the Italian invasion of the province of Tripoli. The African continent had been the center of negotiations and competition between the European powers before World War I, leading to many agreements between the main European powers. Agreements involved Italy, Germany and the Ottoman Empire will also be the focus in this chapter, along with other agreements, in order to understand how the Italian occupation of the province of Tripoli happened. The Bank of Rome in Tripoli and other Italian actors took advantage, culminating in an occupation of Tripoli in 1911. The reaction of the Ottomans backed by the Germans was the declaration of a resistance jihad. The local people supported Tripoli with the help of Ottoman officers. A German health mission was sent from Germany in 1912 in order to help the mujāhidīn (local resistance) in their war against the Italians.Italian politicians considered the province of Tripoli to be part of their territories ${ }^{3}$ and they did not allow any other party to seek economic or political influence over the province. This was obvious from 1907 when, for example, privileges were given to a certain German named Wachs. ${ }^{4}$ Italy was not happy with this decision. An

1 Muhāazaza, Mawāqif al-duwal al-kubrā min al-waḥdā al-'arabiyya, p. 22.

2 Politisches Archiv des Auswärtigen Amts, Allgemeine Angelegenheiten von Tripolis, Das Kaiserliche Konsulat in Tripoli, Bd. 10, vom 16. August 1906 bis 31. Dezember 1908, R16115, Nr. A $19653^{01}$.

3 For a very interesting interpretation of this issue see Novati, Gian Paolo Calchi, L'Africa d'Italia. Una storia coloniale e postcoloniale, Carocci editore, Roma, 2011.

4 No more names were given in the document and no description of who this person was. 
Italian ambassador was sent to the province of Tripoli in order to persuade the Ottoman government of their own viewpoint and to limit such privileges to the Italians. ${ }^{5}$ This subject was the focus of correspondence between the German consul in Tunis and the Italian ministers in $1908 .^{6}$ The correspondences also contained discussion on what had been circulating in Italy of late about the German interests in the province of Tripoli. ${ }^{7}$ Italy was closely following all the events taking place in Tripoli and they claimed that there were German weapon smuggling operations into the province. ${ }^{8}$ Italy also showed suspicion when the Germans acquired properties such as land in the province, trying to establish settlements. ${ }^{9}$ This could also be used to show the increasing German interests, in addition to the establishment of the new direct German navigation line passing Valetta. ${ }^{10}$ The German Hans Banks was behind the establishment of the maritime navigation line ${ }^{11}$ and this helped Germany to greatly increase the volume of its trade with the province. This was more obvious in 1907 when its trade volume was six times higher than in $1906 .{ }^{12}$ Credit was given to the new shipping line and to the German maritime agency Deutsche Levante-Linie shipping company Hamburg 1889-1970, which was managed by two Germans, Banks and Altman, with their ambition to expand their economic activity in Tripoli. ${ }^{13}$ The German maritime agency, with its good services, offered its good reputation to many traders to transport their goods to Tripoli and handle their business with the province. ${ }^{14}$ In addition, the German maritime company Bremer Dampferlinie Atlas was operating in the province of

5 Wathīqā A13216, Mursala min al-safīr al- 'almānī bi- Istānbūl ilā al-khārijīyyā al-'almānīyya, 20/8/1907, Ghānim, “al-Mașālih al-'almānīyya fī Lībiyā”, p. 47.

6 No names were given in the document.

7 Wathīqā 19, Mursala min al-qunșil al-'almānī fì Tūnis ilā wizārat al-khārijìyyā al-'almānīyya, 12/4/1908, Wathā'iq al-'arshif al-siyāsī al-'almānī.

8 Wathīqā 324, Mursala min al-Qāhira ilā wizārat al-khārijīyyā al-'almānīyya, 12/2/1907, Wathā'iq al-'arshif al-siyāsī al-'almānī.

9 Rāfiq, al-'Arab wa al-'ūthmānīyyūn, p. 463.

10 Wathīqā A13216, Mursala min al-safīr al-'almānī bì Istānbūl ilā wizārat al-khārijīyyā al'almānīyya, 20/8/1907, Ghānim, “al-Mașāliḥ al-'almānīyya fī Lībiyā”.

11 Wathīqā 242, Mursala min Istānbūl ilā wizārat al-khārijīyyā al- 'almānīyya, 27/12/1907, Wathā'iq al-'arshif al-siyāsī al-'almānī.

12 Wathīqā A12274, Mursala min Hāns Bānkis (Hans Banks) ilā wizārat al-khārijīyyā al- 'almānīyya qisim al-shu' ūn al-qunșuliyya, 14/12/1907, Ghānim, “al-Mașālị̣ al-'almānīyya fī Lībiyā”, p. 48.

13 Wathīqā A19731, Mursala min al-safīr al-'almānī bì Istānbūl ilā wizārat al-khārijīyyā al'almānīyya, 27/12/1907, Ghānim, "al-Mașālih al-'almānīyyafī Lībiyā”, p. 52.

14 Wathīqā A10621, Taqrīr wakìl al-qunșuliyya al-'almānīyya, bi- Ṭarābulis 'Altumān ḥawala alauḍā' fĩ Lìbiyā, 19/6/1908, Ghānim, “al-Mașāliḥ al-'almānīyya fī Lībiyā”, p. 60. 
Tripoli in 1907 and participated in the increasing volume of trade there. ${ }^{15}$ The Italian government established its own maritime line that linked the port of Tripoli and Misurata with Italy. ${ }^{16}$ The project establishing a new line with Alexandria was supervised by Ernsto Labi, agent for Italian maritime affairs and later the head of the German consular agency in 1909. Labi was responsible for Italian trade activities at this agency starting from late $1907^{17}$ and was simultaneously the manager of the Italian company Navigazione Generale Italiana, a company working in the city of Tripoli. ${ }^{18}$ Italy had also succeeded in opening the Bank of Rome. ${ }^{19}$ However, Italy assumed that these projects alone were not enough to establish strong economic influence able to compete with the German presence. Thus, the Italian ambassador in Istanbul met the German ambassador there and informed him that they did not accept what had been done by the German traders in the province of Tripoli in 1907, and asked him explicitly to limit these trade activities. $^{20}$ The Italians were also alarmed by the position of the Ottoman governor in Tripoli with regard to Germany, especially during the rule of governor Reçeb Pasha (1904-1908) in 1908. Reçeb Pasha refused to give the Italians any privileges and stood against their policy in the province. ${ }^{21}$ Italians started to campaign against such governors and against the German economic interests specifically. This Italian opposition to the German activities reached its peak when the Italian press published some investigations that warned the government against condoning these activities, and described the presence of the Germans as "a German colony in Tripoli”. This was because a former German officer named Hans von Lochow ${ }^{22}$ had bought a piece of land in the province as an investment ${ }^{23}$ following the issuing of the Ottoman land code on properties. The government's reaction was fast. The Italian foreign minister summoned the German ambassador, asking him to provide a full explanation on this issue. The Italian fear esca-

15 Politisches Archiv dess Auswärtigen Amts, Allgemeine Angelegenheiten von Tripolis, Das Kaiserliche Konsulat in Tripoli, Bd. 10, vom 16. August 1906 bis 31. September 1908.

16 Wathīqā 359, Mursala min al-Qāhira ilā wizārat al-khārijīyyā al-'almānīyya, 12/5/1907, Wath'āiq al-'arshif al-siyāsī al-'almānī.

17 Ibid.

18 Politisches Archiv des Auswärtigen Amts, Allgemeine Angelegenheiten von Tripolis, Bd. 10, vom 16. August 1906 bis 31. August 1908, R16115, Nr. A1965301.

19 Wathīqā A12274, Wathā'iq al-'arshif al-siyāsī al-'almānī; for a history of this bank see De Rosa, Luigi, Storia del Banco di Roma: Dal 1911 al 1928, Roma, Banco di Roma, 1983, vol. 2.

20 Wathīqā A19731, Wathā'iq al-'arshif al-siyāsī al-'almānī.

21 al-Zāwi, Wulāt Țarābulis al-ghārb, pp. 281, 284.

22 McClure, William Kidston, Italy in North Africa, An Account of the Tripoli Enterprise, 2013, p. 40.

23 Wathīqā A9389, Risālā mūwajahā min al-safīr al- 'almānī fī Rūmā ilā wizārat al-khārijìyyā, 12/6/1911, Ghānim, “al-Mașāliḥ al-'almānīyya fī Lībiyā”, pp. 67-68. 
lated to the degree that Hans von Lochow was accused of being a spy. ${ }^{24}$ In fact, von Lochow came from Germany to settle permanently in the province of Tripoli and had begun to practice his life as a citizen of the province. He started to do business and trade in Tripoli. He bought a store in this city. In 1908 he extended his activity to the field of agriculture, renting a piece of land near to the center of the city of Tripoli from a British owner named Albert Lak. Later on, in 1911 he managed to buy another piece of land that contained 2.500 olive trees and 18 wells. He sent a request to the German government for agricultural machinery and supplies to extract water and build a network to irrigate the land. ${ }^{25} \mathrm{He}$ announced that he was trying to convince other Germans, specifically from the city of Schwerin, to come to his farm and settle there. ${ }^{26}$ However, Germany showed limited interest in agriculture in the province of Tripoli. ${ }^{27}$ On June 1, 1902, an incident happened to the German doctor Louay Brovsky, who was living in Sūq al-Turk (market in the city of Tripoli) involving harassment by some hired Jews. They had been hired by some Italians to distribute advertisements that insulted him, which led him to sue them in court. As a result, the Italians Lentu and Techichio $^{28}$ were accused of incitement to crime motivated by political reasons. ${ }^{29}$ Their reasons were to keep the province of Tripoli from the political ambitions of the other European countries and to enable Italy to control the province. ${ }^{30}$ Italy was not satisfied with the results of their efforts to fight against the German economic presence in the province. These efforts did not stop any of the German activities. Italy then tried to involve other parties. A dialogue between the Italian and the British government was established. As a result, Marquis di San Giuliano, the Italian prime minister, expressed resentment about this situation. Di San Giuliano stressed at the same time that the Ottoman authorities represented by governors in Tripoli stood against any Italian economic activity while allowing the Germans to carry out many projects there. He used the example of the Germans being granted the right to build the port of Tripoli by the Ottoman government, while the Italians were denied the project. In addition, the Germans were allowed

24 Ghānim, “al-Mașāliḥ al-‘almānīyya fī Lībiyā”, p. 68.

25 Ibid.; Bundesarchiv, Die Handels- und Schifffahrtsverhältnisse mit Tripolis, Bd. 3, vom Januar 1910 bis Mai 1912, Deutsche Tageszeitung, R901/4412, 12.6.1911.

26 Ghānim, “al-Mașāliḥ al-'almānīyya fī Lībiyā”, pp. 68-69.

27 Bundesarchiv, Die Handels- und Schifffahrtsverhältnisse mit Tripolis, Bd. 3, vom Januar 1910 bis Mai 1912, Deutsche Tageszeitung, R901/4412, 12.6.1911, Nr. IIo 855.

28 No more names were provided in the document.

29 Itis not stated in the document if these Italians were official government representatives.

30 Wathīqā 12, Milaf al-wathā'iq al-ijtimā'ìyya, 1/6/1902, shu'bat al-wathā'iq wa al-makhṭūṭāt, al-markaz al-wațanī li-l-māḥafūḍāt wa al-dirāsāt al-tārīkhiyya, Ṭarābulis. 
to buy land in the province while the Italians were not. ${ }^{31}$ The German presence remained significant as they enjoyed special treatment by the ruling class and public alike. Moreover, German goods continued to flow into the province even during the period of Italian occupation, specifically the first year of the invasion. Despite this change in political atmosphere, the country continued to import materials manufactured in Germany, such as iron goods and some sewing machines and other products. ${ }^{32}$ The evolution of German political relations with the province of Tripoli left a positive impact on the economic sector in the province and contributed to the development of commercial traffic between the two parties. As the economy was closely connected to politics, any political progress reflected positively on the various other sectors. In Germany the rapid economic growth during the industrial revolution necessitated creating a new horizon for the disposal of production..$^{33}$ This was accompanied with efforts to support economic institutions by providing the raw materials that were needed from outside. The economic development resulted in increasing the wealth in Germany, which was estimated to be 11.000 million pounds in 1894, while it had reached 17.500 million pounds in $1910 .{ }^{34}$ The economic growth was generated by mechanized industry. Machines were also exported abroad. Economic progress continued to move forward, strengthening the economic sector, which enabled Germany to assume a rank ahead of the United States of America and Britain in $1913 .{ }^{35}$ German trade activities with the province of Tripoli began to grow gradually in the last quarter of the $19^{\text {th }}$ century. German trade with Tripoli began in earnest with the initial stages of opening the German consulate agency in the province of Tripoli in1884 and the consulate in 1909. The arrival of German goods from Saxony, Nuremberg, Hagen and other German cities in the port of Tripoli in 1904 was evidence of the commercial traffic between the two. ${ }^{36}$ Other evidence ${ }^{37}$ could be

31 Wathīqā 119, Mursala min al-sīr 'Adward ilā al-sìr 'Ad. Rūd, maktab khārijiyya, 28/7/1911, Wathā'iq al-'arshif al-siyāsī al-injīilizī, Wathā'iq ghīr muṣanafā, shu'bat al-wathā'iq wa almakhțūṭāt, al-markaz al-wațanī li-l-māḥafūọāt wa al-dirāsāt al-tārīkhiyya, Ṭarābulis.

32 Ghānim, “Taqrīr qunșil al-rāykh al-‘almānī bi-Ṭarābulis”, p. 286.

33 Stoecker, German Imperialism in Africa, pp. 31-32.

34 (no author), “Tharwt Almāniy”, Majallat al-muqtațaf, Majallat 'ilmiyya, șinā'iyya zirā iyya, al-mujalad 36, vol. 4, al-Qāhira, 1910, p. 413.

35 Brown, Jeffrey, al-Madaniyya al- 'Aūrūbbyyā fĩ al-qarn al-tāsi' 'ashr 1815-1914, translated by Moḥammad Aḥmed 'Alī, Dār nahdat Miṣr li-l-țibā'a wa al-nashr, al-Qāhira, 1966, p. 151.

36 Politisches Archiv des Auswärtigen Amts, Allgemeine Angelegenheiten von Tripolis, Bd. 9, vom 1. Juli 1903 bis 15. August 1906, R16114, Nr. A533, 3. Dezember 1905.

37 For an overview of the economy in the wilāya t in the second half of the $19^{\text {th }}$ century see Mantran, Robert, La Libye des origines à 1912, Aix-en Provence, CNRS. 
found in the German documents and statistics about the active economic life in the province of Tripoli and illustrated the greater interest of the German officials in the province. Statistics reflected different aspects related to the economy and wealth there. For example, a German report mentions the number of livestock owned by the local people in the province including horses, sheep, cows, camels, goats and birds. ${ }^{38}$ Some other statistical data found in the German Federal Archive in Berlin relate to a ship called Aegina, which started from Hamburg heading to the port of Tripoli on March 18, 1910. The report stated that the cargo load consisted of $200 \mathrm{~kg}$ wool, $700 \mathrm{~kg}$ buckshot, $300 \mathrm{~kg}$ Chinese ceramics, $3.000 \mathrm{~kg}$ iron products, $2.000 \mathrm{~kg}$ enamel, $24.000 \mathrm{~kg}$ flour, $7.000 \mathrm{~kg}$ tar, $300 \mathrm{~kg}$ leather and $700 \mathrm{~kg}$ shoes cream..$^{39}$ After this ship was offloaded in the port of Tripoli, it was reloaded with new goods from the province of Tripoli. These goods were transported to Egypt and Syria. The goods offloaded in Egypt included: 21.000 kg pigments, 200 $\mathrm{kg}$ wool, $1.000 \mathrm{~kg}$ butter, $1.050 \mathrm{~kg}$ mats. The ship then headed to Syria carrying $1.000 \mathrm{~kg}$ wool, $1.000 \mathrm{~kg}$ goat hair and $950 \mathrm{~kg}$ olive oil..$^{40} \mathrm{In}$ March of the same year, the ship Anatolia departed from the port of Hamburg, carrying $3.000 \mathrm{~kg}$ of tea. It was heading to the port of Tripoli, but first docked in the port of Belgium where the ship was loaded with the following goods: glass for windows $(1.000 \mathrm{~kg})$, sugar $(55.000 \mathrm{~kg})$, sulfur $(11.000 \mathrm{~kg})$, wool $(500 \mathrm{~kg})$, wax $(600 \mathrm{~kg})$. After the ship arrived in the port of Tripoli and was offloaded, it was reloaded with goods from the province and set off to Egypt. ${ }^{41}$ The export of German goods to the province of Tripoli continued during the year 1911 according to reports by Alfred Tilger, the German consul there. It included exchange of products like tea, beer, flour, steel products, machinery, and enamel. The value of exports by Germany to the province of Tripoli reached 56.828 Italian lira. ${ }^{42}$ The following tables $7^{43}, 8^{44}, 9^{45}$ and $10^{46}$ illustrate the amount of exports from the German port of Hamburg to the port of Tripoli, transported by cargo ships (see also Appendix 1).

38 Bundesarchiv, Die Handels- und Schifffahrtsverhältnisse mit Tripolis, Bd. 1, vom Juni 1884 bis Oktober 1904, Bd. 1, vom Juni 1884 bis Oktober 1904, R901/11936, Nr. II 11590.

39 Bundesarchiv, Die Jahres-Handelsberichte des Ksl. Vizekonsulats in Tripolis (Tripolitanien), vom August 1907 bis Juni 1916, Tripolis, R901/4443, Nr. IIㄴ559¹1.

40 Bundesarchiv, Die Kaiserlichen Konsularbehörden in Tripolis, vom Dezember 1912 bis Februar 1914, R901/3608, Bd. 1, Nr. II $-559^{11}$.

41 Ibid.

42 Bundesarchiv, Die Kaiserlichen Konsularbehörden in Tripolis, Bd. 1, Nr. IIํ580 ${ }^{16}$.

43 Bundesarchiv, Die Kaiserlichen Konsularbehörden in Tripolis, Nr. IIํ559.

44 Ibid.

45 Ibid.

46 Ibid. 
Table 7: Goods transported from the port of Hamburg to the port of Tripoli by cargo ship Khythnos on May 19, 1910

\begin{tabular}{ll}
\hline Type of Good & Quantity in Kilogram \\
\hline Sugar & 4.500 \\
Sulfur & 4.000 \\
Iron product $^{48}$ & 3.200 \\
Iron product & 1.900 \\
Glass product & 500 \\
Copper & 500 \\
Sewing needle & 400 \\
Body cream & 400 \\
Furnishing & 300
\end{tabular}

Table 8: Goods transported from the port of Hamburg to the port of Tripoli by cargo ship Anatolia on June 12,1910

\begin{tabular}{ll}
\hline Type of Good & Quantity in Kilogram \\
\hline Beer & 2.000 \\
Paper & 1.200 \\
Rivet & 1.050 \\
Iron product & 900 \\
Shoe cream & 510 \\
Manufactured leather & 350 \\
Iron product & 310 \\
Furnishing & 300 \\
Manufactured leather & 300 \\
Lamp & 250 \\
Essence & 150 \\
(Ammunition) lead & 75 \\
\hline
\end{tabular}

47 All quantities were given in the report in kilograms.

48 It is to be noted that some goods were repeated with different quantities and no justification is provided. 
Table 9: Goods transported from the port of Hamburg to the port of Tripoli by cargo ship Lipsos on July 19,1910

\begin{tabular}{ll}
\hline Type of Good & Quantity in Kilogram \\
\hline Sugar & 59.000 \\
Beer & 1.700 \\
Spiritus & 1.000 \\
Manufactured leather & 1.000 \\
Color & 700 \\
Iron product & 600 \\
Eisenbach & 600 \\
Lamps & 500 \\
Wool material & 200 \\
Sewing machine & 200 \\
Tar & - \\
\hline
\end{tabular}

Table 10: Goods transported from the port of Hamburg to the port of Tripoli by cargo ship Galata on August 13, 1910

\begin{tabular}{ll}
\hline Type of Good & Quantity in Kilogram \\
\hline Sugar & 118.000 \\
Beer & 2.600 \\
Tar & 2.500 \\
Glass product & 1.400 \\
Paints & 1.150 \\
Tea & 900 \\
Iron product & 400 \\
Ceramic & 400 \\
Paper & 350 \\
Manufactured leather & 350 \\
Sewing machine & 250 \\
\hline
\end{tabular}


A report written by German consul Alfred Tilger illustrated that trade from Germany to the city of Benghazi between November 1911 and 1913 included products like beer, tea, flour, iron products, and 'Emil machines'. The German consul estimated the quantities in Italian lira in his report as follows:

- From October to April 1912 the value of goods was estimated to be 56.828 Italian lira.

- $\quad$ From May 1912 to October 1912 the value of goods was estimated to be 128.176 Italian lira.

- From November 1912 to April 1913 the value of goods was estimated to be 110.573 Italian lira. ${ }^{49}$

These tables and statistics referred to the evolution of trade between the province of Tripoli and Germany. These tables show that trade was more organized in the first decade of the $20^{\text {th }}$ century, when the largest and most industrial products were exported to the province of Tripoli through the port city of Hamburg. ${ }^{50}$ The German companies had a significant share in trade between the two parties; one of these companies was C. Sonnenkalb, which was a private company founded in Leipzig and focused on exporting tea to Tripoli. ${ }^{51}$ Moreover, most private companies focused their operations on the mining industries. They made considerable efforts to obtain the approval of the authorities of the province of Tripoli and the central government in Constantinople to pursue their activities in the province. The German private companies were at that time competing with the French companies, which were mainly interested in nitrates, which were very valuable. To give an example the company Aktien-Gesellschaft für Bergbau und Hüttenindustrie in Frankfurt/Main submitted a request to the German government to obtain the approval of the Ottoman authorities that allowed them to search for nitrates in the province of Tripoli in 1911 (see Appendix 2). Moreover, after similar discoveries of nitrates in Tunisia, the company submitted proposals to cooperate with the Ottoman authorities there. ${ }^{52}$ They were already in Tunis and asked to be allowed to work in Tripoli. Other German companies working in the province of Tripoli included a company called Abel und Schellenberg, which started in 1905 and faced strong opposition from the

49 Ibid., Nr. II-580 ${ }^{16}$.

50 Bundesarchiv, Die Jahres-Handelsberichte des Ksl. Vizekonsulats in Tripolis (Tripolitanien), August 1907 bis Juni 1916, Tripolis, R901/4443, Nr. IIํ559.

51 Bundesarchiv, Die Handels- und Schifffahrtsverhältnisse mit Tripolis, Bd. 2, vom 16. Oktober 1904 bis Dezember 1909, R901/4411, Nr. II3021/8.

52 Bundesarchiv, Die Handels- und Schifffahrtsverhältnisse mit Tripolis, Bd. 3, vom Januar 1910 bis Mai 1912, Tripolis, R901/4412, Nr. IIo 855. 
Italian and the French..$^{53}$ In addition, there was a company named Deutscher Lloyd Transport-Versicherungs Gesellschaft Berlin, working in the shipping sector. The company complained several times to the German government aboutthe difficult circumstances in the port of Benghazi, such as it not being able to accommodate the large ships. In 1910, the company asked the German government for insurance against any risks or losses there. ${ }^{54}$ Other companies were working in Benghazi, such as H. Weickert und Enke, managed by the German Karl Sparig who arrived in Benghazi in 1900 to open the first branch of the company. Other German companies that worked in the province of Tripoli included: Hein und Co., Leipzig; Kästner und Toebelmann, Erfurt; Anton Robinson, Hamburg and Schneider und Rothacker, Alexandrien. ${ }^{55}$ The commercial activities were pursued not only via these companies but included interested individual investors engaged in different types of economic activities abroad. German travellers submitted reports and proposals to the German government back at home clearly highlighting and stressing the importance of the province Tripoli for the German trade. Furthermore, they stressed the need for the German government to take positive steps to control the market in Tripoli, which was to help in accessing the market in sub-Saharan Africa. This prompted the German government to give its permission to the industrial and commercial sectors to initiate trade and business operations in the region, despite the small volume of exports from the province to Germany. These included goods like leater, ${ }^{56}$ ivory, goat's hair, ${ }^{57}$ poultry, nitrite and barley. ${ }^{58}$ A 1914 report states orange peel was also exported from Tripoli to Germany. ${ }^{59}$ The Ottoman Empire began different reforms starting with the efforts of Sultan Mahmud II (1808-1839) who began series of reforms called Tanzīmāt. These were extensive and included many sectors such as the economy, education, military and agriculture. ${ }^{60}$ Sultan Mahmud II had initially focused on the conversion of state institutions from the traditional system to modern bureaucratic ins-

53 Politisches Archiv des Auswärtigen Amts, Allgemeine Angelegenheiten von Tripolis, Bd. 9, vom 1. Juli 1903 bis 15. August 1906, R16114.

54 Politisches Archiv des Auswärtigen Amts, Bd. 6, Das Kaiserliche Deutsche Konsulat in Tripolis, vom Mai 1909 bis September, R141611, Nr. Ic 2783.

55 Politisches Archiv des Auswärtigen Amts, R141595, Nr. 489, Leipzig, 20. Oktober 1909.

56 Bundesarchiv, Die Handels- und Schifffahrtsverhältnisse mit Tripolis, Bd. 6, vom Mai 1914 bis April 1915, R901/4415, Nr. 1102225.

57 Nājī, Tārīkh Ṭarābulis al-ghārb, p. 48.

58 Kūrū, Lìbiyā athnā' al- 'ahd al- 'ūthmānī al-thānī, pp. 75, 77.

59 Bundesarchiv, Die Handels- und Schifffahrtsverhältnisse mit Tripolis, Bd. 3, vom Januar 1910 bis Mai 1912, R901/4412, Nr. II ${ }^{\circ} 411$.

60 Minawi, The Ottoman Scramble for Africa, pp. 6-7. 
titutions. Reforms were announced in 1839, when a new tax system replaced the old one. ${ }^{61}$ These reforms were followed by the announcement of the constitution at the time of Sultan Abdul Hamid II in $1876 .^{62}$

The Ottoman sultans tried to rely on European aid for the success of these reforms, particularly Britain, which actually supported them at the beginning. It seems that the Ottoman Empire adopted some clearly European experiences, so that the Empire could cope with the developments in Europe and face the dangers surrounding it. ${ }^{63}$ The European 'aid' was delivered by the British ambassador in Istanbul, who had enjoyed close relations with the Ottoman officials who were responsible for implementing the reforms. Moreover, the Ottomans brought trained Germans to train the military forces Istanbul. ${ }^{64}$ Meanwhile, the Ottomans sent their missions to study and to be trained in Europe, mainly in Germany. The Europeans, particularly the British, had for their part tried to put pressure on the Ottomans for substantial reforms to benefit the Europeans living in the Ottoman Empire and, in particular, that they be be treated equally to the Muslims. They focused their efforts on improving the status of some Christian denominations, such as the Catholics and the followers of the Eastern Church under the authority of the Pope. Those Christians who benefited from the Ottoman reforms were from different European countries such as France, Austria, Russia and protestant Britain. ${ }^{65}$ The beginning of relations went back to before German unity, and were

$\mathbf{6 1}$ Is the compulsory enlistment of people in a national service, most often a military service, Zürcher, Erik-Jan, Turkey: A Modern History, London, 2004, p. 53.

62 See the seminal work of, Shaw, Stanford J. and Ezel Kural Shaw, History of Ottoman Empire and Modern Turkey, vol. 2, Cambrige University Press, Cambridge, 1977, 518p; see also an overview by the Majmū'a min al-bāhithīn, al-Mausū'a al-'arabiyya al-'ālāmīyyā, vol. 6, mū'assasa a'māl al-mausū'a li-l-nashr wa al-tawzī', 1999, p. 245.

63 al-Bustāni, Sulaymān, al-Dawlā al-' ūthmānīyyā qabl al-dustūr wa ba'dah, Zīyāda, Khālid (ed.), Dār al-țalī'a li-l-ṭibā'a wa al-nashr, Bayrūt, 1978, p. 25, 41; Rāfiq, al-'Arab wa al-'ūthmānīyyūn, p. 380; al-Jamīl, Sayyār, al-'Arab wa al-'atrāk al-inbi'ath wa al-taḥdìth min al-'athmana ilā al'almanā, markaz dirāsāt al-waḥdā al-'arabiyya, Bayrūt, 1997, p. 55.

64 al-Ḥuṣarī, Sāți', al-Bilād al-'arabiyya wa al-dawlā al-'ūthmānnyyyā, ma'had al-dirāsāt al'arabiyya, mațaba'at al-risālah 'Ābdīn, al-Qāhira, 1957, p. 60.

65 On the issue of the influence of Europe in the Ottoman Empire, some scholars have relativized the paradigms of imported and exported; see, for example, on the province of Egypt, Lafi, Nora, "Alhadatha wal-idâra al hadâriyya fî Misr al-'Uthamâniyya. As'ila wa tafisîrât" (Modernity and Administration in Ottoman Egypt: Questions and Research Perspectives), in Jadal al-mawḍ̂̀'ìyah wa-al-dhātīyah fī kitābat tārīkh Mișr: Dirāsāt muhdāh ilá al-mu'arrikhah al-kabīrah Nillī Hannā (Objectivity and Subjectivity in the Historiography of Egypt: In Honor of Nelly Hanna), ed. by Nelly Hanna, Nasser Ahmed Ibrahim, al-Hay’ah al-mișrīyah al-āmmah lil-kitāb, Cairo, 2012, pp. 263-273 and for the province of Tripoli: Lafi, Nora, "Mediterranean Connections; The Circulation of Municipal Knowledge and Practices during the Ottoman Reforms, c. 1830-1910", in Another 
either political or religious relations. Prussia had signed a trade agreement with the Ottoman Empire in 1761; it was, in fact, a treaty of friendship and trade and was renewed in 1790 and again in $1803 .{ }^{66}$ Prussia also played an important role in mediating between the Ottoman Empire and Russia to end the war between them through signing the Adrianople agreement in $1829 .{ }^{67}$ The second war between Russia and the Ottoman Empire (known as the Crimean War) in the Balkans and Caucasus had started in 1877, when Greece declared war on the Ottoman Empire and Bulgaria. Russia had endorsed this movement and entered the war. Russia wanted to regain territory lost during the Crimean War and to end the Ottoman rule in the Balkans and the Caucasus. The Ottoman Empire lost part of its territories in these areas in $1878 .{ }^{68}$ Ottoman-German relations also had cultural and religious aspects; for instance, a number of German Christian clergy arrived in the territory of the empire within the framework of missionary activities in the mid$19^{\text {th }}$ century, specifically to Palestine. ${ }^{69}$ These missionary activities continued in different parts of the Ottoman provinces.

Relations evolved over time even during the stage of the declaration of a unified Germany and the rule of Chancellor Otto von Bismarck as a strong politician. Bismarck tried not to interfere in the internal affairs of the Ottoman Empire and what known as the "eastern issue". ${ }^{70}$ However, political developments dictated that he takes a position on current events. He then called for the Berlin Conference in 1878 to settle this conflict, as mentioned above. Bismarck's position was clear: in the Balkan war between 1877 and 1878 he supported the Ottoman Empire. This was driven only by the political and economic interests of Germany. Relations between the two sides had gone through two phases before the First World War. The first was in the time of Sultan Abdul Hamid II and lasted until 1908, when the second phase began with the coming of the Committee of Union and Progress to power in 1908, after ending the reign of Sultan Abdul Hamid II in the

Global City. Historical Explorations into the Transnational Municipal Moment, 1850-2000, ed. by Pierre-Yves Saunier and Shane Ewen, Palgrave Macmillan, New York, Houndmills, 2008, pp. 35-50.

66 Sanū, 'Abd al-Ra'ūf, 'Almāniya wa al-islām fĩ al-qarnayn al-tāsi'a 'ashar wa al-'aishrīn, alfurāt li-l-nashr wa al-tawzi', Bayrūt, 2007, pp. 33-34.

67 Ibid.

68 Gökpinar, Hakan, Deutsch-Türkische Beziehungen 1890-1914 und die Rolle Enver Paschas, Marburg, 2011, p. 96; Menning, Bruce W., Bayonets Before Bullets: The Imperlial Russian Army 1861-1914, Indiana University Press, 1992, pp. 52-57.

69 Sanū, 'Almāniya wa al-islām, p. 31.

70 Ibid., pp. 31, 36. 
same year. ${ }^{71}$ The year 1880 was the starting point of official German-Ottomans relations after German unification. As noted above, the sultans hired German experts in their reform process. The first German to arrive was the officer Helmuth von Moltke the elder (born 1800 in Parchim), who was asked by Sultan Mahmud II in 1838 to assist in modernizing the Ottoman Empire's army. ${ }^{72}$ Von Moltke was the commander of the German armies that defeated the French in the time of von Bismarck. He performed great tasks for the Ottoman state such as training the military forces, and when he returned to his country he monitored the training from there. ${ }^{73}$ The German officer von Dergultich also played an important role in the education and training of the Ottoman army. He was a teacher at the School of Military Staff of the Ottoman Empire. His task was to train the army in the advanced, modern German method to be able to catch up with the European countries in this regard. ${ }^{74}$ There were other German officers, for example von Hofes and Camp Hofes, ${ }^{75}$ in addition to the German army commander Colmar Freiherr von der Goltz, who arrived in Istanbul in (1882-1883) as head of the German military mission. The main task of the mission was to train the Ottoman army forces in accordance with the modern German methods. ${ }^{76}$ To support these efforts, it had been agreed to provide the Ottoman army with German-made weapons, including the cannon called Krupp. This was in the time of Mahmud Şevket Pasha (ruled 1910-1912), an Ottoman general and statesman and grand vizier of the Ottoman Empire. ${ }^{77}$ In addition, a large number of Ottoman students were sent to study in Germany. Some of them joined the military schools in Prussia, while others were enrolled in other institutions in order to benefit from German expertise. ${ }^{78}$ A significant event that revealed the depth of German-Ottoman relations at that time was the visit of the German Emperor Wilhelm II and his wife to the Sultan Abd al-Hamid II in Istanbul. They arrived in Istanbul on board

71 Brrū, Taufīq, 'Alī, al- 'Arab wa al-turk fì al-' 'ahd al-distūri al-'ūthmānī 1908-1914, ma'had aldirāsāt al-'arabiyya al-'ālāmīyyā, jami' 'at al-duwal al-'arabiyya, 1960, pp. 338-339.

72 Bucholz, Arden, Moltke and the German Wars, 1864-1871, Palgrave, 2001.

73 Gökpinar, Deutsch-Türkische Beziehungen 1890-1914, p. 37.

74 al-Ḥuṣarī, al-Bilād al- 'arabiyya wa al-dawlā al-'ūthmānīyyā, p. 70.

75 Brūkilmān, Kāril, Tārīkh al-shu'ūb al-islāmìyya, translated by Nabīh Amīn and Munīr alBa'alabakī, Dār al-'ilm li-l-malāyyīn, Bayrūt, 1974, p. 593; Wahīid, al-Qawl al-mufīd fī ḥukum alsulțān 'Abdul-Hamìd, p. 343.

76 Rāfiq, al- 'Arab wa al-'ūthmānīyyūn, p. 427; Sanū, 'Almāniya wa al-islām, p. 37.

77 Brrū, al-'Arab wa al-turk, p. 348.

78 For an overview on this issue see Römer, Matthias, Die deutsche und englische Militärhilfe für das Osmanische Reich 1908-1914, Frankfurt am Main, Lang, 2007; see also Wahīd, al-Qawl al-mufīd fĩ hụum al-sulțān 'Abdul-Hamìd, p. 343. 
of the German yacht Hohenzollern in $1889 .{ }^{79}$ They were received by Sultan Abd al-Hamid II at a time when most European countries were competing for the favor of the Ottoman Empire. The visit of the German emperor at that time was important in strengthening the relationship between the two parties, as viewed by the Ottoman Sultan..$^{80}$ It is obvious that this visit came within the framework of the consolidation of German policy toward the Ottoman Empire, and it was a milestone in the distinctive political approach to strengthening relations with them. The German emperor tried to take advantage of the international situation by highlighting the role of Germany as a non-colonial power. He visited the Ottoman Empire again in 1898. During this visit he gave a speech in Damascus confirming the strength and resilience of the relationship between the two sides, and clearly pointed out that he would remain faithful to good relations with the Ottoman Turks and the Muslims in general. ${ }^{81}$ This visit can be described as a working visit where bilateral agreements were signed to implement a series of economic projects in the territory of the Ottoman Empire; one of these projects was the Ottoman railway. The construction of the Ottoman railway started in the 1860s and 1870s with the aid of the British. Britain had obtained a concession to create railway lines linking the cities of Izmir and Aydin in Turkey, and in Tunis, another very telling example. ${ }^{82}$ The railway between Izmir and Aydin was opened in 1867. The French also implemented some parts of the railway in Tunis and in the area of Levant (Bilād al-Shām). ${ }^{83}$ Later on, in 1888, a company was established with the help of the Deutsche Bank called Société du Chemin de Fer Ottoman d'Anatolie. This company was created by the Deutsche Bank to operate the Ottoman railway and completely took over its construction. This move came in the context of the competition between Germany and Britain to implement projects related to the infrastructure of the Ottoman state. ${ }^{84}$ In addition, during the visit of the German Emperor in 1898, the Société du Chemin de Fer Ottoman d'Anatolie was granted the privilege of rebuilding Istanbul Haydarpaşa Railway Terminal, which took on

79 Gökpinar, Deutsch-Türkische Beziehungen 1890-1914, p. 49.

80 al-Bustānī, al-Dawlā al-'ūthmānīyyā, p. 42.

81 Rāfiq, al-'Arab wa al-'ūthmānīyyūn, p. 428; Gökpinar, Deutsch-Türkische Beziehungen 1890-1914, p. 48.

82 See Lafi, Nora, "Tunis als Laboratorium osmanischer Modernität: das Beispiel der Vorstadtbahn (1863-1881)", Moderne Stadtgeschichte, special issue "Die Osmanische Stadt“, edited by Nora Lafi and Florian Riedler (guest eds.), 2018-1, pp. 16-25.

83 al-Jamìl, al-'Arab wa al-'atrāk, p. 92; Sanū, 'Almāniya wa al-islām, pp. 4, 9.

84 See for example Geyikdagi, Necla V., French Direct Investments in the Ottoman Empire before World War I, Bloomsbury Academic, London, 2011. 
its classical structure when constructed in $1909 .{ }^{85}$ In addition, a contract was signed assigning the Société du Chemin de Fer Ottoman d'Anatolie and the Deutsche Bank the task of extending the railway line from Izimit to Ankara, with work starting in $1892 .{ }^{86}$ In 1894 , the company was granted a project to extend the railway as far as Konya in Turkey. ${ }^{87}$ Between 1900 and 1908, the company was given the task of extending the railway line between Damascus and Medina. ${ }^{88}$ It was a part of the Ottoman Hejaz railway network that was supposed to extend the line from the Haydarpaşa Terminal in Istanbul beyond Damascus to the holy city of Mecca. A public subscription was opened throughout the Islamic world to fund construction. The railway was to be a waqf. ${ }^{89}$ That is, an inalienable religious endowment or charitable trust. ${ }^{90}$ Moreover, they succeeded in obtaining a privilege permitting them to exploit the mineral resources discovered on both sides of the railway, specifically in Iraq, to a distance of 20 meters. ${ }^{91}$ The Germans realized through their explorers and travellers that Iraq was an oil and mineral-rich country. This was followed by the flow of German capital to Turkey, for example, the signing of a huge contract to build the railway line between Berlin and Baghdad, which was signed by Sultan Abdul Hamid II in 1903. ${ }^{92}$ Britain did not accept this contract and resisted the project in a violent way. The outbreak of the First World War in 1914 was a direct reason to block completion of this project. ${ }^{93}$ Other projects included developing the ports of Basra and Alexandria, establishing the German Bank of Palestine in 1899, cultivating cotton in Adana in 1905, and restoring the ships in the Marmara Sea in 1899, among other projects. ${ }^{94}$ Gene-

85 Jaschinski, Klaus and Julius Waldschmidt, Das Kaisers Reise in den Orient 1898, Bd. 27, Wolfgang Weist, Berlin, 2002, p. 65.

86 Brūkilmān, Tārīkh al-shu'ūb al-islāmìyya, p. 593.

87 al-Jamìl al-'Arab wa al-'atrāk, p. 92.

88 Rāfiq, al-'Arab wa al-'ūthmānìyyūn, p. 428.

89 The word waqf is used in Islam with the meaning of holding certain property and preserving it for the confined benefit of certain philanthropic use and prohibiting any use or disposition of it outside that specific objective, extracted from http://journal.mufad.org/attachments/article/452/7, pdf (March 2016).

90 Nicholson, James, The Hejaz Railway, Stacey International Publishers, 2005.

91 (no author), "al-Dawlā wa al-'Almān”, Majallat al-Manār, Majallat shahrīyya tabḥath fī falsafat al-din wa shu'ūn al-ijtimā' wa al-'umrān, mațaba 'at al- manār, al-Qāhira, 18-61, 333H/1915, p. 472. 92 Hagen, Gottfried, Die Türkei im Ersten Weltkrieg. Flugblätter und Flugschriften in arabischer, persischer und osmanisch-türkischer Sprache aus einer Sammlung der Universitätsbibliothek Heidelberg, Peter Lang, Frankfurt, 1990, p. 15; Yāghī, Ismā'îl Aḥmed, al-Dawlā al-'ūthmānīyyā fì al-tārīkh al-islāmī, maktabat al-'Abikān, 1998, p. 205; Brrū, al-'Arab wa al-turk, p. 38.

93 Jaschinski, and Julius Waldschmidt, Das Kaisers Reise in den Orient, pp. 64-65.

94 Sanū, 'Almāniya wa al-islām, pp. 51, 59. 
rally, Germany managed to acquire $67 \%$ of the total European investments in the Ottoman Empire by $1895 .{ }^{95}$ It should be noted that the rapprochement between the Ottomans and Germans also included the cultural aspect. Germany opened a number of schools in the Ottoman provinces and some states under their rule, such as Palestine, in order to disseminate the German culture and language among the people of the sultanate. ${ }^{96}$ Germany had also established a number of schools along a line parallel to the railway lines that they built. The Germans were involved in building schools in the Ottoman Empire, as were the French and the British. ${ }^{97}$ The Germans tried to spread their educational system and culture. German-Ottoman relationswere improving rapidly when Italy invaded Libya in 1911. Germany decided then to support the Ottoman Empire and tried to bridge the gap in viewpoints between Italy and the Ottoman Empire in Libya. ${ }^{98}$ The situation developed significantly in 1915, when Germany and Turkey agreed to attack Britain in Egypt starting from Libyan territory. Germany also supported the power and authority of the Ottoman Empire in its territories in Asia, where France, Britain and Russia were trying to pressure the Ottoman government to comply with their demands, whether in Syria, where France was involved, or in Armenia, which was within Russian's sphere of interest, or the issue of the railway line Berlin-Baghdad by Britain, an issue that directly affected German interests. ${ }^{99}$ At that time, the German ambassador in London, Prince Karl Lichnowsky, announced that the goal of these countries was not to serve the interests of the peoples of the region, but to divide the areas and subject them to their influence without taking into account the authority of the Ottoman Empire. ${ }^{100}$ Germany also tried to support Russia in their proposal to the Ottoman government to reform the Armenian states within their borders. The German position supported the rights of the Ottomans in the region, while Russia wanted to combine all the categories under one flag to be ruled by European or Christian Ottoman leaders. Germany then insisted on holding a conference, at which they adopted different local reforms primarily conceived to serve the interests of the residents. ${ }^{101}$ The situation in the Ottoman Empire was rapidly changing, especially when Union and Progress

95 Muḥāfaẓa, Mawāqif al-duwal al-kubrā min al-waḥdā al- 'arabiyya, p. 22.

96 Brrū, al-'Arab wa al-turk, p. 339.

97 Hagen, Die Türkei im Ersten Weltkrieg, p. 15.

98 Mīkhā'īl, al-'Ālāqāt al-injìlìzìyya al-lībiyyā, p. 29.

99 Many articles have been published on these issues. See for example the research of Abu Shouk, Ahmed Ibrahim, "The Hijaz railway: motives, results and impacts", Journal of Islam in Asia, 6-1, 2009, p. 1-28.

100 Brrū, al- 'Arab wa al-turk, pp. 567-568.

101 Ibid. 
ended the reign of Sultan Abdul Hamid II in 1908. They declared him deposed by a decision issued by the senate with the approval of shaykh al-Islām Mohammad Diia'al-Din in Istanbul. ${ }^{102}$ This coup received wide acceptance from most of the European countries, in particular France and Britain, and here began the second phase of German relations with the Ottoman Empire. Germany then began to apply the cautious policy designed by their ambassador in Istanbul, Adolf Marschall von Bieberstein. At this stage, Germany realized that it required a more active policy to protect its special relationship with the Ottoman Empire, regardless of who held political power there. Thus, they announced their reservations about this change because of the special relations they had with Sultan Abd alHamid II. However, they were watching very carefully the rapprochement between the new government and the British and the French. Germany then tried to follow a policy of positive neutrality and reservation coping with the course of current events. The new Union and Progress government attempted to introduce new reforms and measures to serve the interests of the Ottomans first, and passed a resolution that included the abolition of foreign concessions; this did not satisfy the European countries. The situation developed further when the Grand Vizier ${ }^{103}$ Mohammad Kâmil Pasha, who supported the Europeans, was isolated. Then the conflict on the demarcation of borders between the province of Tripoli and Tunisia emerged in 1910. The conflict was between the Ottomans and France about the eligibility of the province of Tripoli. Germany then offered to mediate to resolve the crisis peacefully, without resorting to the military option. Germany actually succeeded in resolving the conflict and in forming a Turkish-French committee that took over the task of demarcating the borders. ${ }^{104}$ Despite the fact that France was able to control some of the territory of the province of Tripoli, the issue was settled with the signing of the convention on the final demarcation of the border between the two sides in $1910 .{ }^{105}$ The German-Ottoman relationship remained close until the First World War, by which time Turkey had become very dependent on its ally. One example of this dependence is the commander of the Ottoman

102 al-Shinnāwi, 'Abd al-'Azīz Moḥammad, al-Dawlā al-'ūthmānīyyā dawlā islāmīyya muftara 'alayhā, maktabat al-'anjalū al-mașriyya, al-Qāhira, 1980, p. 117.

103 The Grand Vizier was the prime minister of the Ottoman sultan, with absolute power of attorney and, in principle, dismissible only by the sultan himself; Wittek, Paul, The Rise of the Ottoman Empire, London, 1938.

104 On this issue see the thesis of Ben Sliman, Fatma, Thèse de l'Université de Tunis with an article: Ben Sliman, Fatma, "Frontière et nation. L'exemple de la frontière tuniso-algérienne avant 1881', in idem, Penser le National au Maghreb et Ailleurs, Dar Noqoush Arabia, 2012, pp. 45-63.

105 Shukrī, Moḥammad Fū'ād, Mīlād dawlāt lībiyā al-ḥadìthā wathā'iq taḥrīrahā wa istiqlālihā, vol. 1, (1945-1947), mațba'at al-i'timād, al-Qāhira, 1957, p. 430. 
fleet in the Black Sea, the German general Otto Liman von Sanders, appointed in 1913. He was not new to this position, having supervised the training and development of the Ottoman army in the past. Von Sanders achieved positive results in reorganizing and rebuilding the Ottoman army and sent a report to his government presenting his achievements. ${ }^{106}$ He was accompanied by a number of other German navy officers who occupied important positions in the Ottoman fleet. The Ottoman authorities appointed the task of supervising the castles and fortifications in the Dardanelles to the German officers. ${ }^{107}$ At the outbreak of the First World War, Turkey then declared neutrality, but this position was short-lived, and Germany quickly convinced them to stand on its side after becoming its ally in September 1914. This was preceded by the signing of a treaty between the two sides at the end of July in the same year. ${ }^{108}$ The agreement necessitated the commitment of both sides to neutrality toward the conflict between Austria and Serbia, and they were not supposed to intervene unless Russia entered the war in a way that threatened Germany and in turn Turkey. ${ }^{109}$ Despite the serious political situation, good relations continued between the two parties by enhancing the cultural aspect, in particular, the establishment of the German-Turkish Association (Deutsch-Türkische Vereinigung). Even after the outbreak of the war, German projects continued within the territory of the Ottoman Empire. The Eastern News Agency was established in Berlin in 1915 and was directed by Max von Oppenheim. The news agency played a major role in supporting the Ottoman Empire and the propaganda of the idea of Islamic jihad launched by Oppenheim. The main task of the Eastern News Agency was disseminating propaganda in the Ottoman Empire against the triple alliance, while the agency had also undertaken a significant role in spreading news as well as German culture within the Ottoman Empire. One of the outcomes of its efforts was the establishment of the German-Turkish Friendship House (Haus der Deutsch-Türkischen Freundschaft) in Istanbul in 1917. ${ }^{110}$ The question that arises here is whether Germany was genuinely interested in the completion of these large-scale projects in the framework of bilateral relations and the development of the Ottomans' economic and military institutions, or whether the projects functioned as a means of non-military incursion into the region to undermine British dominance. The answer to this question lies in the fact that Germany had prospered economically and militarily.

106 Sanū, 'Almāniya wa al-islām, pp. 69, 87.

107 Yāghī, al-Dawlā al- 'ūthmānīyyā, p. 220.

108 Shukrī, Mìlād dawlāt Lìbiyā al-ḥadìthā, p. 459.

109 Brrū, al-'Arab wa al-turk, p. 612.

110 Sanū, 'Almāniya wa al-islām, pp. 83, 91-96. 
Germany had controlled some areas in Africa, but remained a minor force in the region. This is why it looked to the Ottoman Empire as a partner first, and second because the latter extended its control over Asia. Asia was considered by the Germans as one of the vital areas for investment and exploitation of mineral wealth, as well as a strong market for their products and industries. Therefore, the Ottoman Empire was of high strategic importance for Germany. Cooperation with the Ottoman ruling powers would enable Germany to communicate with these areas without requiring the permission of the British, who controlled the majority of the sea ports at that time. On the other hand, the Ottoman Empire itself was inneed of an ally among the powerful countries that it could rely on, considering the ongoing political developments that had negative impacts on the empire and ultimately resulted in its losing control over large parts of its territories to the European countries. The political positions of the German government toward the issues related to the Ottoman state, in particular, and the region of the Mediterranean were generally different from the other European countries and this was also the case in the issue of the province of Tripoli.

\section{Political Developments and International Agreements}

The competition between the main European powers made it necessary to engage in negotiations and agreements. It is illuminating to consider main and competing interests of these European powers before discussing the individual agreements.

It was obvious that the African continent was the center of negotiations that led to many agreements between the European powers. This was the starting point in signing agreements between the different parties concerned with colonialism and economic expansion in Africa. The struggle over dividing Africa was conducted parallel to the process of dividing the properties of the Ottoman Empire in the north of the continent. The province of Tripoli was a center of conflict between Britain and France, specifically when both obtained contiguous colonies in Africa. ${ }^{111}$ Britain began to feel the danger of Germany as a powerful new state, especially after its victory over France. It subsequently developed a new policy to maintain its strength within Europe and thereby protect its colonies abroad, and in particular its strategic interests in the Mediterranean, Egypt, and India. ${ }^{112}$ Both

111 al-Dijānī, Aḥmed Șidqī, Lìbiyā qubail al-iḥtilāl al-ițālī au Ṭarābulis al-ghārb fì ’ ākhir al- 'ahd al-'ūthmānī al-thānī (1882-1911), al-mațaba'a al-faniyya al-ḥadìtha, 'al-aṣbagh bi-l-zaitūn, alQāhira, 1971, p. 312.

112 Mommsen, W.J. (ed.), Das Zeitalter des Imperialismus, Frankfurt, 1969, p. 72. 
countries sent a number of travellers under the guise of geographical exploration and the study of natural phenomena, monuments, archeology as well as the history of the region. The reports presented by those travelers make clear that the attention of Britain was directed primarily toward the eastern part of the province of Tripoli, specifically Cyrenaica. The French focused their attention on the south, especially the city of Ghadames and its environs, in order to secure their colonial Empire. This was due to the location of Ghadames on the border with the Algerian territory which had been under French occupation since 1830. Ghadames was close to the Tunisian territory, which had been subjected to French protectorate since 1882. From these two regions they tried to extend their influence to Ghadames. ${ }^{113}$ Soon, Italy entered the conflict. The Italian politicians realized the seriousness and effectiveness of their expansion policy and correspondingly tried to take advantage of the situation in order to achieve their goals. At the beginning, Italy was interested in the eastern part of Africa, in an attempt to realize their ambition to establish a major empire starting from the east coast of Africa. Thus, from this standpoint, Italy struggled politically to gain control over the province of Tripoli, especially since Germany did not have any clear colonial ambitions in the region. ${ }^{114}$ It could be said that the preparation phase started at the beginning of the $19^{\text {th }}$ century, Italy then focused its efforts to gain strong political acceptance from the major countries. As for Austria, it was seeking to establish an alliance with Germany because it did not have the power to enable it to engage in any new conflicts and thus ensure access to new gains through its alliances with Germany or other European countries. Russia's position was different because of strategic interests as it was in an opposite position to the Ottoman Empire. It supported France and tried to prevent its collapse, to keep the balance of power in Europe. At the same time, its strategic interests required it to enter into agreements, even with enemies. ${ }^{115}$ Germany's concern to strengthen its position in Europe led it to enter into a number of agreements and treaties that enabled the state to play an important political mediary role. Externally, Germany tried to secure its strategic objectives in Africa in particular. ${ }^{116}$ These are the goals that led von Bismarck to follow the policy of rapprochement with France to limit the power superiority of the British and at the same time to be an obstacle to any attempt at a French

113 Ḥasan, al-Faqīh Ḥasan, al-Yawmiyyāt al-lïbiyyā, vol. 1 and 2, 958h-1248h (1551-1832), taḥīq Moḥammad al-'Usțā wa 'Ammār Jiḥīdar, markaz jihād al-lībīyyīn li-l-dirāsāt al-tārīkhiyya, Ţarābulis, 1984, p. 21.

114 Zürcher, Turkey: A Modern History, p. 110.

115 'Umar, 'Abdul-'Azīz 'Umar, Tārīkh 'Aūrūbbā al-ḥadīth wa al-mu'āṣir 1815-1919, Dār alma'ārifa al-jami'īya, al-Qāhira, 2000, pp. 196-197.

116 Mommsen, Das Zeitalter des Imperialismus, p. 72. 
attack on Germany. ${ }^{117}$ European powers engaged in agreements to ease the relations between them. Amongst these agreements were those that helped Italy to occupy the province. The political role of and agreements signed by Germany are also viewed as significant. One example is the German Italian agreement of 1887, which helped the Italians to occupy the province of Tripoli. It is argued here that all the conventions and treaties were only a step toward avoiding the opposition of European powers that might prevent Italy from occupying Tripoli. Italy also benefited from other agreements that were signed by other European powers, such as the Anglo-French Agreement.

\section{The Triple Alliance (Germany, Italy, Austria-Hungary) in 1882}

The Berlin Conference is considered the start of the political agreements between the European countries concerning their colonies in Africa and other regions. From that point, Italy tried to work with Germany and Austria-Hungary to attain colonies in Africa. This agreement was known as the Triple Alliance and was settled in $1882 .{ }^{118}$ It focused mainly on the issue of the common defence policy. ${ }^{119}$ Italy considered this agreement a foundation for realizing its ambitions. The same agreement was used by Italy as a defense mechanism against France, to stop France from expanding in the province of Tripoli as it had in Tunisia before. ${ }^{120}$

It is worth mentioning that this alliance was restored several times. First in 1887, when Italy obtained a guarantee of military support from Germany if France tried to change the situation in Tripoli to its advantage or to expand its control over Morocco. ${ }^{121}$ The alliance was next renewed in 1891, then in 1902 and again in $1912 .{ }^{122}$ The three parties worked to emphasize retaining the situation in

117 Conrad, German Colonialism, p. 21.

118 See for example Scott, Ivan, "The making of the Triple Alliance in 1882", East European Quarterly, 12-4, 1978, p. 399; See also al-Dijānī, Lìbiyā qubail al-iḥtilāl al-iṭālī, p. 329; Shukrī, Moḥammad Fū'ād, al-Sanūsīyya dīn wa dawlā, Dār al-fikr al-'arabī, al-Qāhira, 1984, p. 109; Weltgeschichte der Neuzeit, ed. by F. A. Brockhaus in cooperation with Gernot Dallinger und HansGeorg Golz, bpb, Mannheim, 2006, p. 125.

119 al-Mausū' à al-'arabiyya al-'ālāmìyyā, J9, p. 199.

120 Muḥāfaẓa, Mawāqif al-duwal al-kubrā min al-waḥdā al-'arabiyya, p. 26.

121 Tishāijī, 'Abd al-Raḥmān, al-Mas'alā al-tūnīsīyya wa al-siyāsa al-'ūthmānìyyā 1881-1913, translated by 'Abd al-Jalīl al-Timìmī, Dār al-kutub al-sharqiyya, Tūnis, 1973, p. 192; Ismā̄îl, Ḥilmi Maḥrūs, Tārīkh Afrīqiyā al-ḥadìth wa al-mu'āșir min al-kushūfāt al-jughrāfīyya ilā qiyām munazamat al-waḥda al-'afrīqiyya, vol. 1, mu'assāsat shabāb al-jāmi'a, al-Iskandariyya, 2004, p. 263.

122 al-Mausū' à al-'arabiyya al- 'ālāmìyyā, J9, p. 500. 
North Africa. Italy was able to obtain a promise from Austria that the latter would restrain its ambitions in the province. This gave Italy the opportunity to extend its control there. The alliance continued to be the focus of European relations until the First World War in 1914. ${ }^{123}$

\section{Anglo-Italian Agreement in 1887}

Italy did not limit its contact to Germany and Austria-Hungary. Following negotiations with Britain, an agreement of mutual support was published in 1887. It was initially a secret agreement as it had been agreed in $1883^{124}$ based mainly on mutal pledges to maintain the situation as it was. ${ }^{125}$ At the same time, Britain and Italy agreed to limit French influence in the Mediterranean. The main agreement specified that Italy would support Britain in Egypt, and Britain would support Italy in North Africa. ${ }^{126}$ Thus Italy had British support for its political ambitions in Tripoli.

\section{German-Italian Agreement in 1887}

The Chancellor Otto von Bismarck signed a bilateral agreement with Italy; in this agreement Germany, stated the eligibility of Italy to occupy the province of Tripoli. ${ }^{127}$ The position of Germany was clearly against France. It is obvious that most of the European powers tried to isolate France or form coalitions against it. That was the reason behind the German position in favor of limiting the influence of France in Tripoli and Morocco. Germany was prepared to provide military support to Italy when needed. By signing these agreements, Bismarck intended to defend Germany's rights, to confirm its neutrality, and to preserve its position as a major power in Europe. This was in spite of the earlier German position, which was somewhat moderate toward the Ottoman Empire. The German Italian agreement

123 Ibid.

124 al-Ḥarīr, 'Abd al-Maula Ṣaliḥ, "al-Tamhīd li-l-ghazū al-ițāī wa mawqif al-lībīyyīn minhu”, buhūth wa dirāsāt fĩ al-tārīkh al-lībī 1911-1943, vol. 2, majmū'a min al-asātidha wa al-bāhithīn, ishrāf Șalāḥ al-Dīn Ḥasan al-Sūrī wa Ḥabīb Wadā'a al-Ḥisnāwī, markaz jihād al-lībīyyīn ḍidalghazū al-ițālī, Țarābulis, 1984, p.27.

125 Mīkhā'ìl, al- 'Ālāqāt al-injīlizzìyy al-lībiyyā, pp. 16-17; Muhāfaẓa, Mawāqif al-duwal al-kubrā min al-waḥdā al-'arabiyya, p. 26; al-Kaiyāli, 'Abd al-Wahāb et.al, Mausū'at al-siyāsa, vol. 5, almū'assasa al-'arabiyya li-l-dirāsāt wa al-nashr, Bayrūt, 1979, p. 554.

126 al-Dijānī, Lībiyā qubail al-ihtilāl al-ițālī, pp. 330, 332.

127 Maḥrūs, Tārīkh Afrìqiyā al-ḥadīth, p. 263. 
enabled both parties to work in accordance with their own interests. On the one hand, Germany guaranteed to keep Italy within the alliance, and on the other hand, the agreement ensured that an influential power depended on Germany, which paved the way for it to be involved in negotiations with other European countries sharing the same interests in the Mediterranean, such as Britain, France and others. Italy intended to enter into agreements with them to ensure its rights in the region. Article 3 of the treaty mentioned that, in the case that France extended its control over areas in North Africa, Italy would do the same to maintain its position in the Mediterranean. Italy was granted the right to take military action in the French territories in Europe in consultation with its ally Germany in accordance to this treaty. ${ }^{128}$ It is worth mentioning that the same year witnessed bilateral negotiations between Italy and Austria-Hungary, and with Spain. The negotiations discussed the political activity of the Italians, who signed agreements with all the countries that were considered as obstacles ontheir way to occupying Tripoli, and thus had succeeded in signing different agreements with them. ${ }^{129}$

\section{Anglo-French-Italian Agreement in $\mathbf{1 8 9 0}$}

Italy succeeded through this agreement in receiving the explicit support of France and Britain to control the province of Tripoli. This agreement came shortly after the end of the Second Berlin Conference, and was signed because the conference did not refer explicitly to the right claimed by Italy in Tripoli. Thus, Italy engaged in individual negotiations with the major powers which resulted in the signing of an agreement on October 30, 1890 guaranteeing Italy what it wanted to achieve on the North African coast stretching between Egypt and Tunisia. ${ }^{130}$

\section{Anglo-French Agreement in 1899}

Britain and France were considered the largest European colonial powers, which resulted in the many intersections of interests between them that led to several clashes. In order to avoid any negative developments, both sides agreed to enter into negotiations and reached a fair agreement in 1889. In this agreement, zones

128 'Umar, Tārīkh 'Aūrūbbā al-ḥadìth wa al-mu'āṣir 1815-1919, p. 223.

129 al-Kaiyāli, et al., Mausū'at al-siyāsa, vol. 5, p. 554.

130 Mannā', Moḥammad 'Abd al-Razāq, Judhūr al-niḍāl al'arabī fī Lībiyā, Dār maktabat al-fikr, Ṭarābulis, 1972, p. 15. 
of influence for both parties were identified, both in relation to the continent of Africa and to some other regions. ${ }^{131}$ This agreement was viewed with suspicion by Italy, which considered it an obstacle to its presence in North Africa, specifically in the province of Tripoli. Italy's opposition was mainly based on Britain's recognition of the French presence in Saharan Africa and the southern region of the province of Tripoli, which was formalized in the agreement. ${ }^{132}$ In this, France began to seek control over Morocco by initiating many activities in the southern regions of the province of Tripoli and the west on the border with Tunisia, which was of course a French protectorate at the time. The Italians then started to express their concerns and opposition against the French political activities, prompting the French foreign minister to declare in 1899 that his country did not have any colonial ambitions in the province of Tripoli. This paved the way for the signing of several agreements between the two later on. ${ }^{133}$

\section{Italian-French Agreement in 1900}

This treaty was a result of the agreement mentioned above, when Italy sought to work on several major directions to be able to mobilize the European powers to its side. Italy thus realized that there is nothing inappropriate when former enemies become allies of the day. This was accomplished with France, despite the previous disappointments, but that did not hinder the Italian attempts at rapprochement to keep France away from the province of Tripoli, with Italy thus starting to work effectively in that direction. The first step in this policy was to involve Germany as the strongest ally in mitigating the conflict with France. The real beginning can be attributed to $1885,{ }^{134}$ and again in $1898,{ }^{135}$ when Italy took an important step and dropped the obstacles in customs and taxes against France. This paved the way for the creation of a calm situation that accelerated the understanding between the two sides and ultimately led to the convening of a secret agreement in $1900 .{ }^{136}$ This was followed by another agreement in 1901,

131 Mīkhā'īl, al-'Ālāqāt al-injīlizìyya al-lībiyyā, p. 18.

132 al-Dijānī, Lībiyā qubail al-ihtilāl al-ițālì, p. 334.

133 Yaḥya, Jalāl, al-Maghrib al-kabìr al-'ușūr al-ḥadīthā wa al-hūjūm al-isti'māri, vol. 3, al-Dār al-qaumīyya li-l-ṭibā'a wa al-nashr, al-Iskandarīyya,1966, pp. 706-707.

134 Qāsim, Jamāl Zakarīya, "Mawqif miṣr min al-ḥarb al-țarābulisiyya 1911-1914”, al-Majalla altārīkhiyya al- mașriyya li-l-dirāsāt al-tārīkhiyya, al-Qāhira, 1967, p. 308.

135 al-Dijānī, Lìbiyā qubail al-iḥtilāl al-iṭālī, p. 332.

136 Lewis, Mary Dewhurst, Divided Rule: Sovereignty and Empire in French Tunisia 1881-1938, p. 222. 
which focused mainly on Mediterranean politics. ${ }^{137}$ Through these agreements, Italy managed to receive the assurances of the French that they would not involve themselves in any kind of competition in the province of Tripoli. ${ }^{138}$ The deal included the adoption of a dividing line between the areas of influence in the region. In return, Italy accepted the right of France to the occupation of Morocco. ${ }^{139}$ Thus the rapprochement between the two countries led to a division of influence in the two remaining regions of Morocco and Tripol in the north of Africa. ${ }^{140}$

\section{Franco-British Entente Cordiale in 1904}

The Entente Cordiale was a significant part of the series of treaties that the European governments consistently signed during this vital stage of history. These two major powers tried to overcome their conflicts, mainly what was called the first Morocco crisis, to sign an agreement in 1904. The first Morocco crisis occurred when Germany was concerned about the relationship between France and Britain after signing the Entente Cordiale in $1904^{141}$ that ended the long conflicts between the two and declared Morocco a French sphere of influence. The entente made it possible to allow French control of Morocco without undermining the internal balance of power in Europe. Thus, it gave the right to France to land its troops in Morocco and Britain was given absolute control over Egypt. ${ }^{142}$ Germany then tried to highlight the weaknesses of the entente and the new relationship between France and Britain. According to Jones, ${ }^{143}$ Germany made a dramatic movement to use the threat of war to stress to the European powers the significance of consulting Germany on imperial matters. Jones wrote that Kaiser Wilhelm II arrived in the city of Tangier in northern Morocco in 1906 and met the Sultan of Morocco, Moulay 'Abd al-'Azīz alHasan. The German Kaiser then declared Germany’s support for the sultan's independence and the integrity of his kingdom, which made Morocco an international

137 Tishāijī, al-Mas'alā al-tūnīsīyya, p. 234; Qāsim, "Mawqif miṣr min al-ḥarb al-țarābulisiyya”, p. 308; Kāmil, Maḥmūd, al-Dawlā al-'arabiyya al-kubra, Dār al-ma'ārif, al-Qāhira, (D.T), p. 332.

138 Tishāijī, al-Mas'alā al-tūnīsìyya, p. 234.

139 al-Kaiyāli, et. al., Mausū'at al-siyāsa, vol. 5, p. 554; Tishāijī, al-Mas'alā al-tūnīsìyya, p. 334. 140 Ziyāda, Lìbiyā fĩ al-’ușūr al-ḥadìthā, p. 59.

141 See Williamson, Samuel Richard, The Politics of the Grand Strategy. Britain and France Prepare for War in 1904-1914, Ashfield Press, London, 1990; Embry, Kristi N., "The Entente cordiale between and France, 8 April 1904”, extracted from http://www.branchcollective.org/?ps_articles=kristi-nembry-the-entente-cordiale-between-england-and-france-8-april-1904 (March 7, 2016).

142 Hagen, Die Türkei im Ersten Weltkrieg, p. 205.

143 Jones, “Algeciras Revisited”, p. 5. 
crisis. ${ }^{144}$ France tried to offer a compensatory accord with Germany similar to the ones it had managed with other countries concerned with Morocco. However, Germany refused the offer and insisted on using the system of 'diplomatic imperialism' to humiliate France and called for an international conference to decide on the future of Morocco. ${ }^{145}$ The Algeciras conference was thus held in 1906 to solve the first Moroccan crisis. Twelve countries, including Morocco, Britain, Belgium, France, Germany, Spain, and Portugal participated, as well as the American president Theodore Roosevelt. ${ }^{146}$ Germany's aim in the conference was to acquire political and economic gains in Morocco via 'imperialism diplomacy'. However, it failed to achieve the required gains due to many factors. ${ }^{147}$ One of them was the basic judgment errors and diplomatic failure that overestimated the help that could be gained from Russia and Spain. The conference act included decisions to build upgroups of Spanish and French troops to protect the Moroccan ports, which were seen as important for the French colonization of Morocco. ${ }^{148}$ Despite these setbacks Germany tried to find another area in the Mediterranean region. Meanwhile, it worked on enhancing its relationships with other allies such as the Austro-Hungarian Empire and the Ottoman Empire. Consequently, the province of Tripoli was considered in the German political and military strategy before the First World War. Despite the fact that Tripoli was not mentioned explicitly in this agreement, it was a cornerstone in the agreements that were signed after this date. This agreement was a significant turning point in the path that led the major countries to agree on controlling the region on the coast of the Mediterranean. It was the authentic beginning of the division of Europe into the two main encampments that took their final form in the First World War.

\section{The Anglo-French-Italian Agreement in 1906}

Italy did not spare any efforts to get the full consensus and support of Europe. In this regard, Italy entered into a tripartite agreement with Britain and France in 1906. This agreement explicitly identified the areas of influence of each party in North and East Africa and the Red Sea regions. ${ }^{149}$

144 Ibid.

145 Ibid., pp. 5-6.

146 See Collin, Richard H., Theodore Roosevelt, Culture, Diplomacy, and Expansion: A New View of American Imperialism, Baton Rouge, Louisiana State University Press, London, 1985.

147 Jones, “Algeciras Revisited", p. 8.

148 Ibid.

149 Muḥāfaẓa, Mawāqif al-duwal al-kubrā min al-waḥdā al-'arabiyya, p. 27. 


\section{The Italian-Russian Agreement in 1907}

The Italian prime minister had tried to sign an agreement with the tsar of Russia, Nicholas II. The agreement assured Russian support to Italy in the province of Tripoli. In turn, Italy promised to support Russia in the area of the straits of Bosphorus and Dardanelles ${ }^{150}$ and to hinder the expansion pursued by Austria in the Balkans. At that time, it was well known that Austria and Italy were allies. However, Italy was threatened by the expansion of Austria in nearby areas, which motivated it to support Russia more strongly. This agreement was a significant diplomatic support to Italy. In spite of the existence of several agreements that emphasized the need to maintain the territories of the Ottoman Empire by the major European powers, no real action toward this end took place on the ground. ${ }^{151}$ This was mainly because of the emerging ambition of the European countries that made each seek to strengthen its presence abroad. Moreover, each country tried to add new territories to provide the raw materials needed for the development of its economy. For instance, Britain did not respect its agreements with the Ottoman Empire when it obtained control over Cyprus in 1878, which had been under Ottoman rule from 1571. However, when the Italian government expressed its desire to colonize the province of Tripoli, it was supported by the British Foreign Minister Benjamin Disraeli (1804-1881) without reservation. ${ }^{152}$ Thus, Italy was able to sign a number of political agreements considered a political victory. It could take advantage of the conflicting interests of the European countries and successfully exploited these to occupy the province of Tripoli. Taken together all of these events amount to Italy's preparations to colonize Tripoli. The preparing efforts were twofold. Firstly it was performed externally and included signing the agreements mentioned above, secondly there were internal activities concerning the Italian state itself. Internally, the Italian government tried to convince the parliament and the political parties of the idea of invasion.

\subsection{Bank of Rome and Scientific Missions. The Italian Occupation}

Italy started colonization activities relatively late due to the fact that the country was only united in 1870 and lacked the military capabilities. However, Italy had

150 al-Dijānī, Lībiyā qubail al-iḥtilāl al-ițālī, p. 336; al-Kaiyāli, et al., Mausū'at al-siyāsa, vol. 5, p. 554.

151 Sanū, 'Almāniya wa al-islām, pp. 61-62.

152 Mannā', Judhūr al-niḍāl al 'arabì, p. 15. 
changed its policies in line with the rest of the European countries. ${ }^{153}$ One of the Italian objectives behind the establishment of colonies was the political gains that expanding its political and economic influence would bring. It sought economic gains to support its economy by finding new markets for its products and thus creating new sources of revenue for the state. ${ }^{154}$ Italy began to obtain territories on the African continent. It began first in eastern Africa, in Ethiopia, in 1882, but suffered a bitter defeat in the battle of Adwa in $1896 .{ }^{155}$ Italy then directed its attention to North Africa, specifically toward Tunisia at first, but lost it to France. Italy then proceeded to take the necessary measures to carry out a military operation there. The government intended to prepare the ground in the province economically, politically and culturally before the declaration of war on the Ottoman Empire there. The Italian politicians were aware of the seriousness of the stage that they were preparing for, because the political situation in Tripoli was different from the rest of its neighbors in North Africa. This region was under the direct authority of the Ottoman Empire, which was one of the obstacles that Italy faced. The other obstacle was the local population. The Italian policy-makers had to be careful about their steps in pursuing their colonial goals and they started to work internally to prepare Italian public opinion to accept the idea of sending troops to war on the coast of North Africa. This was considered a challenge after their defeat in East Africa. This was intensified when the left-wing came to power and assured people it would improve their standard of living and alleviate all the economic and social problems. Moreover, they launched the idea of migrating to new lands that would be later Italian colonies. ${ }^{156}$ As the Ottoman Empire, specifically in North Africa, was regarded as disintegrating by the French and British governments, Italy launched a huge economic investment in Tripoli and, through schools for the Jewish population, created a division between Jews from Europe and Jews from Tripoli. ${ }^{157}$ The Italians were very focused on all the internal and external affairs of Tripoli, and the Italian government became very sensitive to everything that would oppose its activities there, especially the efforts of

153 Shukrī, al-Sanūsīyya dīn wa dawlā, p.103.

154 al-Ḥarīr, "al-Tamhīd li-l-ghazū al-ițālī wa mauqif al-lībìyyīn minhu”, p. 29.

155 Qāsim, "Mawqif mișr min al-ḥarb al-țarābulisiyya”, p. 308; Ismā'îl, Tārīkh al-'arab alhadith, p. 262.

156 Mannā', Judhūr al-nị̣āl al 'arabī, p. 14; Shukrī, al-Sanūsìyya dīn wa dawlā, p. 106.

157 See the work of Simon, Rachel, "The Relations of the Jewish Community of Libya with Europe in the Late Ottoman Period and Jewish-Muslim Relations in Libya in the $19^{\text {th }}-20^{\text {th }}$ Centuries", in "The Socio-economic Role of the Tripolitanian Jews in the Late Ottoman Period", in Abitbol, Michel (ed.), Communautés juives des marges sahariennes du Maghreb, The Ben-Zvi Institute Jerusalem, 1982, p. 253-63. 
any other European country. One of these activities by the Europeans was the issue of identifying the borders of territories belonging to Turkey and the British in the border area between the province of Tripoli and Egypt in 1904. ${ }^{158}$ When the Italian government was informed of this agreement in 1904, they immediately contacted the British government requesting an explanation. Britain then replied that this issue was not existent. The same happened with France, which repeatedly tried to gain territories at the expense of the Ottoman Empire in the border region between the province of Tripoli and the former Ottoman province of Tunis colonized by France. ${ }^{159}$ This prompted Italy to propose that the consuls of Italy and Britain, as well as one employee of the Ottoman state, should solve the problem of the eastern and western borders. The Ottomans refused this proposal, and considered the issue an internal affair of the sultan. Their refusal did not deter the Italian government from repeating the attempt, insisting on having an active and major role in the conflict, but all their efforts failed. On the same issue, the Italian ambassador to the Ottoman Empire announced in 1891 that Italy would not accept any activities that might change the balance of power in the Mediterranean region, especially by the French. Italy was aware of the attempt by France to strengthen its presence in Tripoli through varied cultural activities, as it tried to open French schools in the province. This effort also included great pressure put on the Ottoman Empire. For instance, the French government made several requests to the Ottoman government to facilitate the work of its ambassador in Tripoli. In this instance, France succeeded in getting the permission of mutașarrifizyya of al-Khums to build a church and a residence for priests in the city of al-Khums in $1903 .^{160}$

The question that arises here is what the motives of France were in implementing all these activities inside the province of Tripoli at this particular time considering the agreements they had already signed? The answer to this question was that, at this stage, France did not intend to gain benefits from Tripoli but intended to use it to exercise pressure on the Italian government to compromise and reach a settlement satisfactory to both parties in the region of North Africa. ${ }^{161}$ The press also played a major role as the Italian newspapers had been writing about the activities of France in the disputed areas with the Ottoman Empire.

158 Egypt had been occupied by Britain since 1882.

159 Nājī, Tārīkh Ṭarābulis al-ghārb, p. 186.

160 Jhān, 'Alī Moḥammad, al-Ḥayāt al-thaqāfiyya bi Miṣrāta athnā' al-ḥukm al ūthmānī al-thān̄̄ 1835-1911, markaz jihād al-lībīyyīn li-l-dirāsāt al-tārīkhiyya, Ṭarābulis, 2007, p. 77.

161 Muḥāfaẓa, Mawāqif al-duwal al-kubrā min al-waḥdā al-'arabiyya, p. 27. 
They worked to highlight the attacks by France on the borders of the province. ${ }^{162}$ They did not ignore the news that the French were trying to obtain the privilege of building the port of Tripoli in $1905 .{ }^{163}$ The Italian government then started to investigate this information supported by the press. This prompted France to immediately declare it as rumors to reassure the Italian government. ${ }^{164}$ The Italian Minister of Foreign Affairs named Tatony ${ }^{165}$ explained this issue in the Italian Senate. The Italians then assigned their ambassador to the Ottoman Empire to clarify the iltalian policies with the Ottoman sultan. He argued that they were only intended to maintain the situation in the region and that their goals were purely peaceful. The main argument used by the Italians to explain the situation was that if the Sultan granted any privileges in the province of Tripoli to other countries, this would negatively affect their economic interests and would therefore inevitably lead to force the government to change its policy toward the Ottomans. ${ }^{166}$ Germany was also attacked by the Italian press because Italy sought to strengthen its in the internal affairs of the province. The newspapers then doubted the German intentions, stressing that their activities were not only economic in nature but that they sought to control the province politically. ${ }^{167}$ The newspapers indicated openly and directly that Germany was seeking to take control of the important port of Tobruk by leasing it from the Ottoman government, but went even further by stressing that there were negotiations taking place between the Ottomans and the Germans. ${ }^{168}$ Germany was also subjected to propaganda from the French and British newspapers, as they tried to depict Germany as suspicious and mistrusted considering its activities in North Africa generally and in Tripoli, specifically. That was after Germany had tried to mediate between the Ottomans and the French on the issue of the borders between Tripolitania and Tunisia. The French press wrote then that Germany was seeking to internationalize the issue, especially with regard to the oasis of Janet, ${ }^{169}$ located

162 Tishāijī, al-Mas'alā al-tūnīsīyya, pp. 193, 206-207.

163 A plan of the harbour of Tripoli was drawn a bit before; for this question, see Plan du port de Tripoli de Barbare levé en 1816 et 1821, Dépot général de la Marine, 1823.

164 Yahya, al-Maghrib al-kabir, pp. 716-717.

165 As the name mentioned in the reference.

166 Yahya, al-Maghrib al-kabìr, p. 717.

167 Politisches Archiv des Auswärtigen Amts, Allgemeine Angelegenheiten von Tripolis, Das Kaiserliche Konsulat in Tripoli, Bd. 11, vom 1. Januar 1909 bis 31. März 1911, R16116, "Die Deutsche Flagge in Tripolis”, La Grande Italia, Nr. 2, 8. Januar 1911.

168 Ismā'īl, Tārīkh al-'arab al-ḥadìth, p. 266.

169 For mode details on this issue see Pottier, René, La Tripolitaine vue par un Français, Dar al-Fergani, Tripoli, n.d. 
near the confluence of influence between the province of Tripoli and Algeria, and Germany was accused of defending the Ottoman Empire. ${ }^{170}$ Generally, Italy was supported by the flexibility shown by the European countries that measured the political situation according to their economic strategic interests and all agreed that the Italians should focus their efforts on their goal of occupying Tripoli. In doing so, they intended to keep Italy away from other regions like the Balkans, for example, and thus Italy found the support of all the Europeans. 1889 could be considered as the actual beginning of the Italian penetration into the province of Tripoli, especially with regard to the cultural aspects like schools, language and mass media, and extending the work of the Bank of Rome. ${ }^{171}$ The Bank of Rome was expanding inside the province, ${ }^{172}$ as it opened branches in Benghazi, ${ }^{173}$ in Darna, ${ }^{174}$ and in Gharyan in $1907^{175}$ in addition to the branch in the city of Tripoli. It conducted initially normal banking activities, then started to buy agricultural land from the local population and paid very high prices, ${ }^{176}$ prompting many of the local people to sell their land. Moreover, the bank started to grant the local population loans. A guarantor was needed to repay the loan later if the recipient was unable to repay it. A debtor who was unable to repay had his land confiscated. ${ }^{177}$ This helped the Italians to establish a huge economic base in the province of Tripoli. The Bank of Rome also established companies that came to be administered directly by the bank officials and succeeded in attracting a number of Libyan citizens to work for these companies. ${ }^{178}$ Information indicated that the number of these workers ranged

170 Politisches Archiv des Auswärtigen Amts, Allgemeine Angelegenheiten von Tripolis, Bd. 1, vom Juni 1881 bis 22. Februar 1883, R16106, Berlin Tagblatt, Nr. A13737, 8.8.1906.

171 'Abd al-Qādir, 'Ișmat, Daūr al-nuwāb al-'arab fī majlis al-mab' ūthān al-'ūthmānī 1908-1914, al-Dār al-'arabiyya li-l-mausū'āt, Bayrūt, 2006, p. 245.

172 Qāsim, "Mawqif miṣr min al-ḥarb al-ṭarābulisiyya”, p. 307.

173 Mirt, Azjān, "Nashāṭ mașraf Rūmā min khilāl al-wathā'iq al-'ūthmānīyyā”, translated by 'Abd al-Karīm abu- Shuwaīrib, Majallat al-wathā'iq wa al-makhṭūṭāt, 19/ 20, markaz jihād allībīyyīn li-l-dirāsāt al-tārīkhiyya, Ṭarābulis, 2003-2004, p. 178.

174 Sebald, "Eine unerschlossene Quelle zur Geschichte Libyens: die Artikel des deutschen Afrikaforschers Gottlob Adolf Krause (Malam Mosa) aus dem Jahre 1911 zur italienischen Kolonialeroberung", in Libyen in Vergangenheit und Gegenwart, ed. by Burchard Brentjes, Halle, 1979, pp. 21-22.

175 Ghānim, 'Imād al-Dīn (translator), Taqārīr bi 'that al-ṣalīb al-aḥmar al- 'almānī fī al-ḥarb allībiyyā al-ițāìyya, 1911-1912, rev. and intr. by Ḥasan 'Alī Fahmī Khishīm, mațāba' al-thawrā al'arabiyya, Țarābulis, 1987, p. 43.

176 Maḥmūd, Ḥasan Sulaymān, Lībiyā bain al-māḍi wa al-ḥādir, mu'assasat sijil al-'arab, alQāhira, 1962, p. 220; Mannā', Judhūr al-niḍāl al'arabī, p. 15.

177 al-'Aqād, Șalāḥ, Lỉbiyā al-mu'āṣira, Ma'had al-buhūth wa al-dirāsāt al-'arabiyya, almațba'a al-faniyya al-ḥadīthā, shāri' al-aṣbagh bi-l-Zaitūn, 1970, p. 12.

178 Sebald, "Eine unerschlossene Quelle zur Geschichte Libyens”, p. 21. 
between 200 and 300. The activities of the bank varied to a great extent and were all done under the guise of investments in the province and the introduction of modern industries that included e.g. an ice factory, an olive oil factory and varied other projects. All these projects aimed to introduce the Italian influence into the province. As a result, Italy managed to acquire $22 \%$ of total foreign trade with the province of Tripoli in 1911. ${ }^{179}$ The staff of the bank were involved in collecting as much information as possible about the province while trying to win the trust of the local people and prepare them to accept the Italian presence on their land. ${ }^{180}$ The Italian government started to establish a number of Italian schools within the province, ${ }^{181}$ in addition to the Italian schools already opened in 1876 during the reforms (Tanzimāt) and in $1878^{182}$ (both were located in the center of the city of Tripoli). Later on, the Italian government opened eight more schools in some other coastal cities such as Benghazi, in which they opened five schools. In Derna there were two schools, and three schools were opened in al-Khums in 1911. ${ }^{183}$ Italian sources estimated the number of students enrolled in these schools at about 3.000 pupils in 1911, a figure reflecting a widespread interest in learning the Italian culture. The project was supported by the Italian government, which dedicated 46.000 Italian liras per year to ensure its success. ${ }^{184}$ It is worth mentioning that some of those schools taught in both Italian and Arabic, side by side, as a way to attract a large number of Arabs who wished to teach their children the Arabic language and refused to let them into schools that taught only Italian. It is notable that education in these schools was free. ${ }^{185}$ Italy also sent a number of scientific and medical missions to identify some of the natural phenomena, the geography of the area, and to study some medicinal plants and herbs. al-Harīr mentioned that these were sometimes connected to colonial aspirations and not just scientific missions. ${ }^{186}$ They succeeded in collecting accurate information

\section{Ibid.}

180 al-Ḥarīr, "al-Tamhīd li-l-ghazū al-ițālī wa mauqif al-lībīyyīn minhu”, p. 32.

181 al-Ḥasan, Ḥasan, al-Anzima al-sīyāsiyya wa al-dustūriyya fì Lubnān wa sa'ir al-buldān al'arabiyya, Bayrūt, 1967, p. 389.

182 Ḥasanīn, 'Alī al-Ṣādiq, "al-Madāris al-ițālīyya wa tațawuruha fī Lībiyā 1835-1950”, a'māl al-nadwā al-'ilmiyya al-thāminā allatī 'uqidat bi-l-markaz fī al-fatra min 26-27/9/2000, ed. by Moḥammad al-Ṭahir al-Jarārī, markaz jihād al-lībīyyīn li-l-dirāsāt al-tārīkhiyya, Ṭarābulis, 2005, pp. 431-432.

183 Sebald, "Eine unerschlossene Quelle zur Geschichte Libyens", p. 21.

184 Ismāōìl, Târīkh al-'arab al-ḥadìth, p. 265.

185 al-Zāwī, Jihād al-abțāl, pp. 39, 47.

186 al-Ḥarīr, 'Abd al-Maula Șāliḥ, "al-Taḥarukāt al-sīyāsiyya al-ițālīyya, wa al-tamhīd li-iḥtilāl Lībiyā”, Majallat al-buhūth al-tārīkhiyya, 10-2, markaz jihād al-lībīyyīn li-l-dirāsāt al-tārīkhiyya, Ṭarābulis, 1987, p. 14. 
about the geography of the province. ${ }^{187}$ The Italian government sent a group of specialists to study the nature of the coast of the province of Tripoli. These specialists reached the city of Tripoli as sponge hunters and actually worked in this field there, which allowed them to carry out comprehensive surveys of the coast and present to a thorough study to the Italian authorities and the Ottoman Empire. ${ }^{188}$ Among the most important of those missions was that of Count Sforza, which arrived inTripoli in 1910. Sforza, who was the head of the mission, claimed that they had come to search for minerals, and specifically to detect phosphate. However, the real motive behind their activities was revealed later: they were on a military mission to draw strategic military maps. ${ }^{189}$ The Ottomans then arrested the members of the mission and some of them were put in jail; the O'Shea Lausanne treaty (between the Italians and the Ottomans) freed them in 1912. ${ }^{190}$ The Italian government also encouraged Italian citizens to migrate to the west of the province of Tripoli, ${ }^{191}$ and by 1911 there were 620 Italian citizens there. ${ }^{192}$

Some Ottoman governors played a major role in hindering the Italian mission in Tripoli; these include Reçeb Pasha (1904-1908). Reçeb Pasha was aware of the seriousness of the situation; this was revealed in his many efforts to introduce reforms and to develop the military forces in Tripoli. In addition, he established schools as an effort to raise the level of education and awareness of the local population to the level demanded by the events and possess the ability to confront Italy, as he was aware of the Italian attempt to occupy the country. ${ }^{193}$ Reçeb Pasha was not the only governor who stood up to the Italian project. Governor Ibrahim Pasha (1910-1911) was also highly aware of the extent of the Italian colonial project and influence over the country. He very soon began to fight against this project by organizing the conscription and training of volunteers from the local population. Ibrahim Pasha also worked hard to obstruct the activities of the Bank of Rome, and contacted the government in Istanbul to provide the latest on Italian colonial intentions, but he did not receive any response to those reports. ${ }^{194}$ Instead, the Ottoman Empire issued an order to immediately open a branch of the

187 Shukrī, al-Sanūsīyya dīn wa dawlā, p. 12; Ḥasan, Lībiyā baina al-māḍi wa al-ḥạ̣̄ir, p. 219; al-'Aqād, Lìbiyā al-mu'āṣira, p. 12.

188 Lūtiskī,Vladimir, Tārīkh al-aqțār al- 'arabiyya al-ḥadīth, translated by 'Afīfa al-Bustāni, revised by Yūrī Rūshīn, Dār al-taqadum, Moscow, 1973, p. 368

189 Ismāēìl, Tārīkh al-'arab al-ḥadìth, p. 265.

190 Shukrī, Mīlād dawlāt Lìbiyà al-ḥadìthā, p. 428.

191 Nājī, Tārīkh Țarābulis al-ghārb, p. 131.

192 Sebald, “Eine unerschlossene Quelle zur Geschichte Libyens”, pp. 20-21.

193 al-Zāwi, Wulāt Tarābulis al-ghārb, pp. 281-282.

194 Ibid., p. 284. 
Ottoman Bank in the province of Tripoli in $1906,{ }^{195}$ to work together with their Agricultural Bank, which had been established previously. The government then decided to reduce the profit margins from $6 \%$ to $4 \%$ in response to the Bank of Rome's activities to access land. They also issued a decree to facilitate all the procedures for the citizens and not to impose tough conditions. Moreover, they emphasized to the bank's administration that in cases of losses they should resort to the Ministry of Finance to compensate themand not to impose taxes on the people of Tripoli. However, the government was cautious in implementing these procedures, which were discussed secretly. The governor was asked to be cautious in implementing these procedures so as not to attract the attention of the Italians or other European countries. The government of Ibrahim Hakki Pasha (1910-1911) in the Ottoman capital was not in a position to fulfill the serious responsibilities entrusted to it (it was in a difficult situation due to the onset of decline within the empire at the same time), which is why it disregarded these warnings when alerted to the imminent danger in the province of Tripoli. ${ }^{196}$ The government then took a very dangerous act in response to the pressures of the Italians and isolated the governor Ibrahim Pasha in September 1911, and did not send someone to take on his responsibilities. This allowed the Italians to reveal their true intentions ${ }^{197}$ and take the initiative to send parts of their fleet to the Mediterranean, particularly off the coast of Tripoli. They demonstrated their force as a prelude to the invasion. At that time the country was suffering of poor conditions due to the negligence of the government of Ibrahim Hakki Pasha, which withdrew a large number of soldiers sent to Yemen for the necessities of security. The government did not replace the soldiers. ${ }^{198}$ The internal political situation in the province of Tripoli helped Italy to succeed in most of these activities; the province was being neglected by the government in Istanbul due to the difficult political situation in the empire (distance between the province and the center of government). Not enough reforms had been conducted in the province, especially the reforms required at this crucial stage, except for the efforts of individual governors in Tripoli. On September 27, 1911, Britain and France confirmed an alliance against the Italians and Ottomans. An eco-

195 The Branch of Benghasi was opened in 1911 and closed in 1912, like in Tripoli. The LondonGalata-Istanbul Izmir opened in 1856 and Djeddah in 1912 and closed in 1916. For a more detailed history see Autheman, André, La Banque impériale ottomane, Comité pour l'Histoire Economique, Paris, 1996; see also Billiotti, Adrien, La Banque Impériale Ottomane, Paris, 1909.

196 al-Wāfī, Moḥammad Abd al-Kārīm, al-Ṭarīg ilā Luẓān, Dār al-Furjānī, Ṭarābulis, 1977, p. 69. 197 Qāsim, “Mawqif miṣr min al-ḥarb al-țarābulisiyya”, p. 310.

198 Prätor, Sabine: Der arabische Faktor in der jungtürkischen Politik: Eine Studie zum osmanischen Parlament der II. Konstitution (1908-1918), Berlin, 1993. 
nomic and strategic competition pushed Italy to engage more in the direction of a military occupation in the region. ${ }^{199}$ The Ottomans did not estimate the Italian motives in the way they deserved; they thought that if they provided all the necessary measures and procedures that they could deal with the situation.

\section{The Italo-Turkish War in 1911}

Italy was determined and declared war on the Ottoman Empire on September 29, 1911. The Italian military fleet was composed of 23 ships carrying 40.000 troops. They attacked the center of the city of Tripoli. Another military fleet was directed toward the east; some historical documents state that the fleet consisted of 36.000 troops, in other sources 32.000 troops $^{200}$ arrived on 19 ships. They were under the command of General Ottavio Bricola and their destination was the city of Benghazi. ${ }^{201}$ Thus the Italian navy sequentially attacked the coastal cities of Tripoli and al-Khums, Benghazi, Darna and Tobruk in the first days of October. ${ }^{202}$ They first concentrated their attack on the port of Tripoli, and succeeded in sinking a number of ships anchored there. They were also able to destroy the maritime telecommunication line that connected Tripoli to Istanbul on October 3, $1911 .^{203}$ This was the first day of the Italo-Turkish war in Libya. The Italians were able to reach the city of Tripoli on October $5 .^{204}$ The German Ministry of Foreign Affairs had received news of the attack via a telegraph sent by Alfred Tilger. ${ }^{205}$ Faced with

199 al-'Aqād, Lìbiyā al-mu'āṣira, p. 13; Brrū, al-'Arab wa al-turk, p. 328.

200 Hūwīdī, Mușțafa 'Alī, al-Ḥaraka al-wațanìyya fī sharq Lìbiyā khilāl al-ḥarb al-'ālāmīyyā al-'ūlā, revised by Șālāḥ al-Dīn Ḥasan al-Sūri, markaz jihād al-lībìyyīn ḍid al-ghazū al-ițālī, Țarābulis, 1988, p. 27.

201 Mannā', Judhūr al-niḍāl al- 'arabī fì Lìbiyā, p. 19; Kāmil, al-Dawlā al-'arabiyya al-kubra, p. 332. 202 See Gallica BNF: Tripoli, guerre italo-turque (Italo-Turkish War) [camp de l'armée italienne au pied de remparts]: [photographie de presse]/[Agence Rol], Documents iconographiques, 1911, Tripoli, and see also Guerre italo-turque [militaires italiens dans une maison de Tripoli]: [photographie de presse]/[Agence Rol], Documents iconographiques, Consultable in Gallica; Maḥmūd, Lìbiyā baina al-mā dị wa al-hạạdir, pp. 221-222.

203 McClure, William Kidston, Italy in North Africa, an Account of the Tripoli Enterprise, Darf, London, 1986, p. 41.

204 Tshanar, Frānntis wa Frītis Shitīyyāt wa Salwā al-Khamāsh, Tārīkh al-'ālam al'arabī, Dār ṣādir, Bayrūt, 1975, p. 234; al-Tilīsī, Khalīfa Moḥammad, Ma'arik al-jihād al-lībī min khilāl al-khiṭaț al-ḥarbīyya al-ițālìyya, al-munsha'a al-'āmmā li-l- nashir wa al-tawzi' wa al-i'lān, Ṭarābulis, 1982, p. 19; al-Zāwī, Jihād al-abțāl, p. 80.

205 Bundesarchiv, Die Handels- und Schifffahrtsverhältnisse mit Tripolis, Bd. 5, vom März 1913 bis April 1914, R901/4414, Nr. II 3798. 
this violent attack there was no option available to the local population and the local government other than to resist using the available weapons, which were few and some were very old. ${ }^{206}$ Despite the lack of weapons and the lack of sufficient forces, they resisted and were accompanied by some of the Turkish officers. Nashat Pasha, the governer of the province of Tripoli in 1911, was in charge. He was based in the western region, and had taken the area of al-Aziziyah has, a military base. ${ }^{207}$ The Ottoman Empire then entered into direct negotiations with the Italians in order to settle the war in Libya. ${ }^{208}$ The negotiations were held in Lausanne in Switzerland and resulted in the signing of an agreement between the two sides, known as the Treaty of Lausanne, on October 18, 1912. ${ }^{209}$ The Ottomans then withdrew from the province of Tripoli, which was then named Libya. The Ottomans announced that Libya was being granted independence, even if Libya was then occupied by Italy. The Ottomans left Libya to face its destiny to Italy. ${ }^{210}$ However, the Ottomans retained some of their concessions in Libya, such as the appointment of staff for religious affairs in 1912, ${ }^{211}$ and allowing the people to pray for the Ottoman Sultan in mosques.

The residents of Libya were exposed to a harsh policy by the Italians during the occupation. ${ }^{212}$ The Italians restricted the movement of people and placed a blockade on the whole country to prevent the arrival of any aid or weapons. They also placed strict controls on the borders, which led to a severe shortfall in food and other consumer goods that had been imported. This blockade had very negative impacts on the prices of the available goods, which became much more expensive. The drought that hit the country in 1911 made the situation worse. ${ }^{213}$ According to a report ${ }^{214}$ in the German political archives on the general situation

206 Sebald, “Eine unerschlossene Quelle zur Geschichte Libyens”, pp. 28-29.

207 al-Zāwī, Jihād al-abțāl, p. 93.

208 Since 1911 Province (wilāyāt) of Tripoli was named Libya; see Larfaoui, Mahmoud-Hamdane, L'occupation italienne de la Libye: les préliminaires, 1882-1911, L'Harmattan, Paris, 2010.

209 Bundesarchiv, Nr. A5735; Vandewalle, Dirk, A History of Modern Libya, Cambridge University Press, 2006, p. 25; Wright, Libya: A Modern History, p. 28.

210 Tshanar, Tārīkh al-'ālam al'arabì, p. 234.

211 Brūkilmān, Tārīkh al-shu'ūb al-islāmīyya, p. 601.

212 See on this issue the picture: Guerre italo-turque (Italo-Turkish War) [militaires italiens derrière une barricade dans une rue de Tripoli] [Image fixe]: [photographie de presse]/[Agence Rol], Gallica, BNF Paris, Publication: [Novembre 1911]. Reference 17067; see also 10-10-11, Tripoli [groupe de militaires marchant dans une rue] [Image fixe]: [photographie de presse]/[Agence Rol] Gallica, BNF Paris, Publication: [Octobre 1911], Reference Number 16590.

213 Politisches Archiv des Auswärtigen Amts, Tripolis, Bd. 7, vom Januar 1910 bis Dezember 1912, R141612, Nr. 691, Mai 1912.

214 Ibid. 
in Tripoli in 1911, the agricultural harvest of that year was very poor and poverty was widespread among the population of the city of Tripoli. It also stated that the number of beggars on the streets had greatly increased. The report mentioned that this situation was not unique to this city and that the same phenomenon could be witnessed in other parts of the country. Moreover, the report stated that prices of buying or renting land or houses had increased significantly. ${ }^{215}$ The report illustrated that the many battles that had taken place had damaged agriculture fields in rural areas. Consequently, there was a severe reduction in the production of oranges, olives, palm trees and others. ${ }^{216}$

\subsection{Jihad in Libya and the German Position toward it}

The Libyan fighters were called mujāhidin and the whole war against the Italians declared as jihad. The term Libyan mujāhidin is also used in this book to describe the mujāhidin in Libya and it does not mean that this was a nationalist movement. ${ }^{217}$ Many of the mujāhidin refused to recognize the treaty of Lausanne and decided to proceed with jihad. They regarded the treaty of Lausanne as having surrendered the country to its enemies. Thus, the Islamic jihad and the Libyan jihad were officially announced as a response to Italy's declaration of war against the Ottoman Empire in September 1911. Even if jihad in Libya at that time was not a nationalist movement, the jihad movement was composed of many local movements. The majority of the local movements were coordinated by tribal leaders. Using the weapons that were available to them, they launched attacks on Italian encampments, cities, or centers of occupation. It is worth noting that the majority of fighters in the various independent local movements were not trained soldiers, but took part as part of an ideological battle against Italian occupation. Neither did they come from any particular social class, but represented all sections of Libyan society. In addition to mujāhidin they were also referred to as volunteers. These fighters were joined by troops from the Ottoman forces, who had a greater degree of military training.

Among the mujāhidīn was Sulaymān al-Bārūnī, who was one of the mujāhidīn leaders in Yafren in the Western Mountains, Moḥammad Sūwf al-Maḥmūdi who was the tribal leader of al-Mahamīd tribe in north east of the city of Tripoli, and

215 Ibid.

216 Ibid.

217 See Simon, Rachel, Libya between Ottomanism and Nationalism: The Ottoman Involvement in Libya during the War with Italy, 1911-1919, Klaus Schwarz, Berlin, 1987. 
Moḥammad 'Abd al-llāh al-Būsayfī, one of the mujāhidīn leaders in the Western Mountains and others. ${ }^{218}$ One of the well known mujāhidīn was Sayyid Ahmed al-Sharīf al-Sanūsī, who belonged to al-Sanūsīyya political - a religious Sufi order, tribe and political movement ${ }^{219}$ that played a major role in the history of Libya. The movement and its relations with the Ottomans were important. ${ }^{20}$ Following the outbreak of war between the Italians and the Libyan mujāhidin in Libya, Germany sent a number of journalists to report on what was going on there and to evaluate the situation. Not only Germany, but also Britain and France had reporters in Libya. ${ }^{221}$ Nevertheless, the Italian politicians were suspicious of the activities of these reporters and put many obstacles in their way. ${ }^{222}$ They also imposed strict censorship on all reports that were sent to Europe before they were published. These actions led some German journalists and others to stop their work and return to their countries, reporting the harassment of the Italian authorities. ${ }^{223}$ As the conflict developed and, following a number of unequal battles between the Libyan mujāhidin and the Italians, the Italian government released a decree on November 5, 1911 announcing its suzerainty over all of Libya. ${ }^{224}$ In return, Germany issued a rejection of this decree, followed by France and Britain. ${ }^{225}$ The German rejection meant that this decree was not granted internati-

218 Khishīm, Ḥasan 'Alī, Șafahāe min jïhādanā al-wațanī, Dār maktabat al-fikr, Ṭarābulis, 1974, p. 54. 219 Ibrāhīm, Maḥmūd, al-'Alāmah Moḥammad bin 'Al̄ al-Sanūsī al-jazā'iri mujtahidan mujāhidan 1788-1859, dīwān al-mațbu'āt al-jami'īya, al-Jazā'ir, 2009, p. 124.

220 al-Sanūsìya was a religious movement in Libya at the beginning of the $19^{\text {th }}$ century founded by al-Mahdi al-Sanūsī and gained his name, al-Sanūsī is the title of all the sons of al-Mahdi alSanūsī, who took the leadership. They are the followers of al-Mahdi al-Sanūsī politically, ideologically and personally, see Ibrāhīm, al- 'Alāmah Mohammad bin 'Alì al-Sanūsī, p. 124.

221 On this issue see Tripoli, les officiers étrangers suivant la guerre [Image fixe]: [photographie de presse]/[Agence Rol] November 1911, Gallica, BNF, Paris, Reference 17327.

222 See Labranca, Nicola, La guerra Italiana per la Libya: 1913-1931, Il Mulino, Bologna, 2012, 293p.

223 Ghrīfintīs, Ghayūr Ghafūn, Tārīkh al-ḥarb al-lībiyyā al-ițālìyya, translated by 'Imād al-Dīn Ghānim, revised by al-'Amīn al-Ṭāhir Shaqlīlā, markaz jihād al-lībīyyīn ḍid al-ghazū al-ițālī, Ṭarābulis, 1986, p. 112.

224 See on this issue: Tripoli, l'état-major italien pendant la lecture de l'acte d'annexion [Image fixe]: [photographie de presse]/[Agence Rol] Octobre 1911, Gallica, BNF, Paris, Reference 17330. And see also Tripoli, le général Caneva lisant l'acte d'annexion; à sa droite, l'amiral Borea Rica [Image fixe]: [photographie de presse]/[Agence Rol] Gallica, BNF Paris, Publication: [Octobre 1911], Reference number 17313; Māsāi, Būl, al-Waḍa' al-dawali li-Tarābulis al-ghārb: nușūs almu'āhadāt al-lībiyyā al-firinsīyyā ilā nihāyat al-qarn al-tāsi' 'ashar, translated by Mohammad al-'Alāqī, revised by 'Alī Ḍawī, markaz jihād al-lībīyyīn li-l-dirāsāt al-tārīkhiyya, Țarābulis, 1991, p. 153; Ghrīfintīs, Tārīkh al-ḥarb al-lībiyyā al-ițālīyya, p. 123.

225 Rāshid, Aḥmed Ismāî̄l, Tārīkh 'aqțār al-maghrib al-'arabī al-sīyāsī al-ḥadìth wa al-mu'āṣir (Lìbiyā - Tūnis - al-Jazā̉ir - al-Maghrib - Mūritaniya), Dār al-nāhḍa al-'arabiyya, Bayrūt, 2004, p. 40. 
onal legitimacy. However, this uncompromising attitude did not last long, especially after the signing of the Treaty of Lausanne in 1912. It seemed that if Italy did not succeed in imposing political and military pressure on the Ottoman Empire and some European countries, Italy could not sign that agreement. It led to the international recognition of the Italian existence in Libya even if it was not explicitly announced. Even if Germany initially opposed Italy's aims, strategic interests and the political and economic relations with the rest of Europe determined its position in the end. Thus, the German government in Berlin was primarily serving its interests, which is why it had declared its opposition at first, and then changed its decision and declared its support of the Italians. They maintained their strong relationships with the Ottoman Empire in parallel with their support for the Libyans. ${ }^{226}$

A number of German officers were fighting on the frontline alongside Enver Pasha and his mujāhidin in the city of Derna in the far eastern part of Libya against the Italians. These officers sent their reports to the government in Berlin; among those officers was the Baron von Dalwing. ${ }^{227}$ Furthermore, they had taken on the task of helping the Turkish leaders in the management of war battles and organizing the mujāhidin and those Germans can be described as guides for military operations. ${ }^{228}$ This German position was echoed by the leaders of the Islamic Libyan jihad, in particular by Sulaymān al-Bārūnī, who led the jihad movement in the western part of the country, specifically the area of the western mountains. He trusted the German Emperor Wilhelm II and believed he was pursuing a moderate policy toward Libya. He also worked to spare the country from entering war on a number of occasions. From this point, Sulaymān al-Bārūnī (1872-1940) was in contact with the German emperor several times, especially after the signing of the Treaty of Ouchy in 1912 between the Italians and the Ottomans. His initial message dating to December $27^{\text {th }}, 1912$ required Germany to recognize Libya as an independent state that had its existence based on that convention. On January $4^{\text {th }}$, he sent another message asking the German government to protect the Libyans and their rights. He asked the emperor of Germany to do his best to influence the king of Italy, considering that they were allies, and make him announce the independence of Tripoli. He also asked the emperor to impose pressures on the Italians to

226 Hagen, Die Türkei im Ersten Weltkrieg, p. 13.

227 Ghrīfintīs, Tārīkh al-ḥarb al-lībiyyā al-ițālīyya, p. 354.

228 Rāthmān, Lūthar, "Niḍāl al-sha'b al-lībī ḍid al-isti'mār”, Muhaḍarāt al-mawsam al-thaqāfī al-awal 1979-1980, ed. by Moḥammad 'Abd al-Sālam al-Jafā’irī, markaz jihād al-lībīyyīn ḍid alghazū al-ițālī, Țarābulis, 1989, p. 212. 
withdraw their forces from Libya. ${ }^{229}$ He pointed to the uncivilized methods pursued by Italy in Libya, including but not limited to paying some local leaders to stop fighting against them and join the Italian army, which would lead to a weakening of the Libyan front. ${ }^{230}$ Sulaymān al-Bārūnī resumed his contact with Germany in 1913.

Following the signing of the Treaty of Ouchy in Lausanne (1912), the leaders of the independence movements were divided as to how to respond to the new developments. One faction argued for continued conflict with the Italian forces, whilst the other faction preferred the option of negotiation on the basis of the treaty. Sulaymān al-Bārūnī belonged to the former faction, even going so far as to proclaim the independence of Tripolitania. As Italian hostilities continued, he decided to travel to Turkey, where he was elected a general for the West Mountain Front in the Turkish Council of Commissioners. The majority of the independence fighters and a number of tribal leaders supported al-Bārūnī and by this stage he was also supported by the Ottoman state. ${ }^{231}$ His requests to Germany to support the nationalist movements stressed the country's desire and ability to be independent from foreign rule. Germany continued its support for the independence movement in Libya which became more explicit during World War I. Germany's position had become very complicated due to the alliance with Turkey. They were seeking to use Libya as a base to attack the allies in North Africa (Britain, France and Italy). At the same time, Italy controlled Libya, which until that point was neutral and had not announced joining any of the parties to the conflict in World War I. Thus, Germany had to take steps to ensure the achievement of its interests. Germany tried to influence Sayyid ${ }^{232}$ Ahmed al-Sharif, the commander of the mujāhidin in eastern Libya, to stop the war against the Italians and to start fighting the British in Egypt. However, when Italy declared Italy's accession to the Allies, Germany began to reconsider its position and pursued a completely different policy; it began providing financial and military support to the mujāhidīn in their war against the Italians. ${ }^{233}$ German forces managed to pene-

229 al-Shaqrūnī, Tawfīq 'Ayād, "Wathā’iq 'an tahrukāt Sulaymān al-Bārūnī al-dawlīyya”, Majallat al-wathā’ iq wa al-makhțūtạt, 6-6, markaz jihād al-lībīyyīn li-l-dirāsāt al-tārīkhiyya, Tarābulis, 1991, pp. 148, 150.

230 Politisches Archiv des Auswärtigen Amts, Allgemeine Angelegenheiten von Tripolis, vom April 1912 bis April 1913, R16118, Nr. A115.

231 al-Ghatmī, Maḥmūd al-Mahdī, “Sulaymān al-Bārūn̄”, Majallat al-wathā'iq wa al-makhțūṭāt, 19-20, markaz jihād al-lībīyyīn li-l-dirāsāt al-tārīkhiyya, Țarābulis, 2003-2004, p. 251.

232 A religious position and title for the leaders of al-Sanūsìyya movement in Libya. See Morimoto, Kazuo (ed.), Sayyids and Sharifs in Muslim Societies: The Living Links to the Prophet, Routledge, 2012. 233 Rāfiq, al-'Arab wa al-'ūthmānīyyūn, p. 47; al-Ḥasan, al-Anżima al-sīyāsiyya wa al-distūriyya, p. 390 . 
trate the blockade imposed by the Italian troops on all sea ports that could be used to bring weapons into Libya. The blockade was evaded using German submarines. The aid was unloaded at the cities of Sirte, Misurata and Tobruk in 1915. At the same time, German aid reached the mujāhidin more indirectly, as in the case of a convoy loaded with about 2.000 Mauser guns, which had been made in Germany. This was in addition to six mountain defenders with ammunition and some other equipment. The weapons were delivered by an officer working for the British occupation forces in Egypt, who delivered the weapons to the mujāhidin across the Egyptian-Libyan border. ${ }^{234}$ In the eastern part of Libya, German support for the men of the Libyan resistance was a source of great concern to the Italians as well as to the British in Egypt. They had been watching the situation closely, inspecting the German intervention and continuous aid provided to Sayyid Ahmed al-Sharîf via Istanbul. ${ }^{235}$ The delivery of Germany military aid to the Libyan mujāhidīn was not an easy job as the country was under strict observation by the Italian forces, especially the borders. In addition, the British supported Italy in their observations, particularly after Britain's recognition of the Italian ambitions in Libya in the Secret Treaty of London (April 26, 1915) and the British-Italian agreement of July $31,1916 .{ }^{236}$ Following these agreements, Britain intensified its efforts to prevent German interference in Libya. ${ }^{237}$ It was obvious that Germany was working to strengthen its position as a political force in the Mediterranean, despite the Turco-Italian signing of the Treaty of Ouchy in October 1912, which confirmed the influence of these two countries over the region and implied that other countries should refrain from interfering in the situation. Despite this, Germany continued to support the Libyans in their armed struggle against Italy. ${ }^{238}$ Although the social history of Tripoli is not the main focus of this study, it is worth noting that the population of this region suffered badly as a result of the political and military conflicts. The Italian leadership imposed a blockade on Tripoli to prevent weapons and other forms of support for the mujāhidin from entering the city. At the same time, surveillance of the borders

234 Ramaḍān, Bashīr, al-Qìyādā wa al-'imdād fĩ ḥarakat al-jihāed al-lībī, markaz jihād al-lībìyyīn li-ldirāsāt al-tārīkhiyya, Ṭarābulis, 1999, p. 396; Rāthmān, "Niḍāl al-sha'b al-lībī ḍid al-isti 'mār”, p. 214. 235 Wathīqā 371, 16 September 1914, wathā'iq al-kharijīyyā al-injīlizzìyya, shu'bat al-wathā'iq al-ajnabīyya, al-markaz al-wațanī li-l-māḥafūọāt wa al-dirāsāt al-tārīkhiyya, Țarābulis.

236 J.C. Hurewitz, The Middle East and North Africa in World Politics. A Documentary Record, vol. 2, “British-French Supremacy, 1914-1945”, Yale University Press, New Haven, 1979, p. 146.

237 Rāthmān, "Niḍāl al-sha'b al-lībī ḍid al-isti 'mār”, p. 241.

238 Wathīqā bidūn Tarqīm, al-'arshif al-'ūthmānī, Mursala min wazarat al-ḥrbìyya al'ūthmānīyyā ilā al-safārā al- 'ūthmānīyyā fì Lundun, shu'bat al-wathā'iq al-ajnabìyya, al-markaz al-wațanī li-l-māḥafūọāt wa al-dirāsāt al-tārīkhiyya, Ṭarābulis. 
led to a decrease in the amount of food supplies that could enter the country. This created a rise in food prices and a decrease in the market availability of basic foodstuffs. The situation was complicated further by a drought in the same year, which also caused a sharp drop in the agricultural output of the country. A report in the German political archives describing the general situation in west Tripoli in 1911 refers to the poor yield of this year, linking it to a rise in poverty and an increase in the number of beggars in the streets. The author of the report notes that the situation was not limited to Tripoli, but that other regions of Libya were affected by the same degree of poverty, with the same results. The same document notes that the military conflict between the mujāhidin and the Italians had a negative effect on the agricultural yield of the region and that the orange trees, olive trees and date trees were particularly badly affected. ${ }^{239}$

Despite the orders issued from Istanbul on October 4, 1911 to the Ottoman troops to withdraw from Libya and the subsequent withdrawal from al-Khums, Derna and Benghazi in the same month, some Turkish officers decided to stay in the country and help the Libyans to resist Italian colonialism. ${ }^{240}$ Even if they were few in number, they still managed to influence the jihad process. They were divided into two sections: the first remained in the areas surrounding the city of Tripoli, with the other directed toward Cyrenaica in the east, where they received commands from 'Azīz al-Māṣrī in Benghazi, while in Derna the leadership was entrusted to Muștafa Kemal Atatürk. ${ }^{241}$ The chief of command for the region of Cyrenaica was Enver Pasha, who was able to organize the mujāhidin there, while being the field commander in several attacks against Italian soldiers. For instance, he commanded the attack on the Italian fortifications in Lombardia and Calabria, ${ }^{242}$ but Enver Pasha was forced to leave Libya in 1912. The commander in the eastern region was then 'Azīz al-Māșrī. ${ }^{243}$ Then he was transferred to the area of al-Jaghbūb, where Sayyid Ahmed al-Sharīf al-Sanūsī lived and informed him of the latest developments and what Turkey had decided concerning Libya, and that Sayyid Ahmed al-Sharīf al-Sanūsī was now in charge. Enver Pasha then left to Turkey.

The resistance was united in eastern Libya under the leadership of Sayyid Ahmed al-Sharif al-Sanūsī, who moved to the east of the country and took

239 Politisches Archiv des Auswärtigen Amts, Tripolis, vom Januar 1910 bis Dezember 1912, R141612, Nr. 691, Mai 1912.

240 See Falls, Ewald J.C., Drei Jahre in der libyschen Wüste. Reisen, Entdeckungen und Ausgrabungen der Frankfurter Menasexpedition (Kaufmannsche Expedition), Herder, 1911.

241 Ziyāda, Lìbiyā fì al-'ușūr al-ḥadìthā, p. 82; Mannā', Judhūr al-niḍāl al arabī, p. 26.

242 Shukrī, al-Sanūsìyya dīn wa dawlā, pp. 138, 140.

243 Rāshid, Tārīkh 'aqțār al-maghrib al-'arabì, p. 38. 
over. ${ }^{244}$ The political and military developments led the Libyans to regroup and take a stand to defend their land. They entered into fierce battles against the Italians from the beginning of the invasion along the Libyan coast. The most important battles were al-Hani, (called Shara' al-Shat), the coastal route in October 1911, when the militants managed to repel the Italian attack, despite the disparities in equipment and numbers of soldiers. ${ }^{245}$ The battle of Sydī Abd al-Jālīl in the west of the city of Tripoli on June 8,1912 was recognized by the Italians themselves as one of the most effective battles. The Italians wanted to extend their control over the entire west coast of the country. ${ }^{246}$ At this stage, the mujāhidin led by Sulaymān al-Bārūnī, Moḥammad 'Abd al-llāh al-Būsayfī, and Moḥammad Sūwf al-Mahmūdi were able to resist the Italians for a period of time. During that time, many battles took place, such as the battle of Jendouba on March 23, 1913, which was one of the most important battles in the history of the Libyan jihad. Despite the courageous resistance of the mujāhidin, they were unable to stand for long against the Italian forces, which were well equipped. The result of this battle was the defeat of the mujāhidin and the success of the Italians in controlling the mountainous area in the western part of the country. Later on, they were able to control the entire western region of South Libya, including Swanee bn Adam, and Sidi Kraim Alqrba in eastern Libya. This was the first battle under the command of Sayyid Aḥmed al-Sharīf, member of the al-Sanūsīyya movement. ${ }^{247}$ The battle took place on May 16, 1913. The mujāhidin were able to defeat the Italians and forced them to reorganize their forces and to recognize the entry of the al-Sanūsìyya movement as a new factor in the war. The Italian forces in Libya experienced repeated defeats at the hands of the Libyan mujāhidin despite the differences in disarmament and number of troops. The famous battle of Gasr $\mathrm{Bu}$ Hadi took place on April 28, 1915. It represented a painful defeat to the Italians, and is considered one of the most important battles in the history of the Libyan jihad. It showed clearly the development of the military capability enjoyed by the mujāhidin and their ability to take advantage of the prevailing conditions. The Italian defeat forced the Italian commander Colonel Miani to flee the battlefield with the rest of the soldiers. ${ }^{248}$ This defeat concurred with their defeat in Europe at the hands of the German and Austrian troops and the awful defeat in the battle

244 Maḥmūd, Lībiyā baina al-māẹi wa al-ḥādir, pp. 224-225; Shukrī, al-Sanūsīyya dīn wa dawlā, pp. 138,146.

245 Ismā'īl, Tārīkh Afrīqiyā al-ḥadìth, p. 273; Rāshid, Tārīkh 'aqțār al-maghrib al-'arabī , p. 41. 246 al-Tilīsī, Ma'arik al-jihād al-lībì, p. 30.

247 Evans-Pritchard, Edward E., "The Senusi of Cyrenaica”, Journal of International Africa, 15-2, 1945, p. 61; see also Slousch, N., "Les Senoussiya en Tripolitaine”, Revue du monde musulman, 1907. 248 Ḥasan, Șafaḥāt min jihādanā al-wațan̄i, p. 23. 
of Kaporta. The position of the Italians became critical, especially in view of the resistance of the Libyan mujāhidin to the sophisticated Italian weapons at that time. This played a major role in weakening the power of the Italians and forcing them to retreat toward the coastal cities. ${ }^{249}$ In order to maintain its survival in Libya, Italy had withdrawn its military garrisons scattered around the city of Tripoli, Zuwarah and al-Khums in the west and center of the country. The situation of the Italian troops was critical until $1917 .{ }^{250}$ They were pushed to take refuge in the French military post deployed on the Libyan-Tunisian border and on the Algerian border. ${ }^{251}$

\section{The Ottoman - al-Sanūsīyya}

The al-Sanūsīyya movement began as a religious movement. The leader, Sayyid Moḥammad Ibn Ali al-Sanūsī (1787-1859), was born and grew up in the Ottoman province of Algeria but settled in Libya after years of travel. The beginning of the movement was in the area of the Green Mountain in eastern Libya. ${ }^{252}$ The founder of the movement first settled in Cyrenaica, but in 1854 decided to move the headquarters of the movement to the south of the country to be isolated from direct contact with the power of the the Ottoman rulers at the time. He decided on the al-Jaghbub Oasis and used it as a base for his operations and home for the al-Sanūsìyya family and their followers from $1856 .{ }^{253}$ It seems that the choice of alJaghbub was influenced by several factors. Al-Jaghbub was far from the centers of political power in the North Africa region: the French, who were stationed on the western border, specifically in Tunisia and Algeria, the Ottoman Empire in Libya, and the British in Egypt on the eastern borders of the country. Al-Jaghbub was also situated on the caravan traderoute, which was helpful for the al-Sanūsiyya movement in terms of the financial returns that this could bring, which would be

249 Hagen, Die Türkei im Ersten Weltkrieg, p. 189; Qāsim,"Mawqif miṣr min al-ḥarb alțarābulisiyya”, p. 340.

250 al-Tilīsī, Khalīfa Moḥammad, Ba'd al-qurạabìyya dirāsa fī tārīkh al-isti'mār al-ițālī bi Lìbiyā (1922-1930), al-Dār al-'arabiyya li-l-kitāb, Lībiyā-Tūnis, 1978, pp. 5, 11.

251 al-Turkī, 'Arūsīyya, Fuṣūl fī tārīkh al-ḥaraka al-wațanīyya al-tūnīsīyya al-mu 'āṣira, maktabat 'alā' al-dīn, Șafāqis, 2005, p. 52.

252 See Brūkilmān, Tārīkh al-shu'ūb al-islāmīyya, p. 651; al-Sayyid, Yūsuf, Fajr al-ḥaraka alislāmīyya al-mu'āṣira al-Wahābiyya - al-Sanūsīyya - al-Mahdiyya, Miṣr al-'arabiyya li-l-nashir wa al-tawzī', al-Qāhira, 2000, p. 60.

253 Marx, Geschichte Afrikas, p. 90; 'Amīsh, al-Tārīkh al-sīyāsī, p. 87; al-Sayyid, Fajr al-ḥaraka al-islāmīyya, al-mu'āṣira, p. 60; Shukrī, al-Sanūsìyya dīn wa dawlā, p. 65; Yāghī, al-Dawlā al'ūthmānìyyā fì al-tārīkh al-islāmì, p. 29. 
important in providing a livelihood for the followers living there..$^{254}$ The protection that this location allowed the followers to exercise over the caravan traders also enabled them to expand their sovereignty in the region. Given the numbers adhering to the al-Sanūsìyya movement and the popularity and authority that its followers enjoyed in the region, the Ottoman Empire treated it with a certain wariness. Relations between the Ottomans and al-Sanūsīyya movement had been characterized by mutual caution since the settlement of the movement in Libya. The Ottomans avoided direct confrontation, preferring instead a policy of cooperation when possible. Their relations tended to be characterized by the principle of mutual interests. For example, a decree was issued from Istanbul exempting the al-Sanūsìyya movement from paying taxes. This came as a proactive step to bridge the gap and enhance relations. ${ }^{255}$ The movement had the task of protecting and securing the interior affairs in the region in which they lived. Thus, al-Sanūsìyya began to play a significant political and social role in Libya. The al-Sanūsīyya movement performed its power in territories stretching from Benghazi to the frontiers of sub-Saharan Africa. ${ }^{256}$ The movement's leaders led the Islamic jihad in eastern Libya during World War I, which increased pressure on the Ottoman Empire to maintain cordial relations with them. Accordingly, the two parties signed an agreement on their united struggle against European colonialism. ${ }^{257}$ The same interest brought the al-Sanūsìyya movement closer to the Ottoman rulers to confront the British in Egypt, as both parties considered it to serve their interests. ${ }^{258}$ The goal that brought them together at this time was fighting the British and the Italians during World War I. ${ }^{259}$

254 On the al-Sanūsìyya see Triaud, Jean Louis, Tchad 1901-1902. Une guerre franco-libyenne oubliée? Une confrérie musulmane, la Sanûsiyya, face à la France, L'Harmattan, Paris, 1988, 208, 32 p., and Triaud, Jean-Louis, La légende noire de la Sanûsiyya. Une confrérie musulmane saharienne sous le regard français (1840-1930), Editions de la Maison des Sciences de l'Homme, Paris and Aix-en-Provence, 2 vols., Institut de Recherche et d'Etudes sur le Monde Arabe et Musulman (IREMAM), 1995, 1151p.

255 al-Sharīf, Miftāḥ al-Sayyid, Masīrat al-ḥaraka al-wațanīyya al-lībiyyā al-Sanūsīyya, maktabat dār al-istiqlāl, al-Qāhira, 2008, pp. 84, 88.

256 Minawi, The Ottoman Scramble for Africa, p. 29.

257 Marx, Geschichte Afrikas, p. 149.

258 al-Sharīf, Masīrat al-ḥaraka al-wațaniyya al-lībiyyā, p. 178; for the roots of these confrontations see Boahen, A. Abu, Britain, The Sahara and the Western Sudan, 1788-1861, Oxford: Clarendon Press 1964.

259 Wathīqā 47, al-Wathā'iq al-ițālīyya, al-majmū' 'ā al-'ūlā, translated by Shamis al-Dīn 'Urābī, i'dād al-Furjānī Sālim al-Sharīf, markaz jihād al-lībīyyīn ḍid al-ghazū al-ițālī, Ṭarābulis, 1989, p. 166.; Hūwīdì, al-Ḥaraka al-wațanìyya fī sharq Lìbiyā, p. 51. 


\subsection{German Declaration of Neutrality toward Libya and German Health Missions}

The German government's position was explicitly stated following the announcement of Italy's war on Turkey in Libya. Germany tried to stop the war, especially when the Ottoman Sultan submitted a request to some European countries. Germany then took the initiative despite the fact that it was not confident that it would be a success. The resolutions stated by Germany were thought to be moderate and included proposing a truce to end the military conflict, giving Italy some areas in Libya and the necessity of negotiation and reconciliation between the two parties. ${ }^{260}$ The direct order from the German emperor was to conduct the mediation in favor of the Ottoman Empire with Italy, stressing that the effort should be undertaken as a long-term project, rather than a one-off attempt. This position was very different from that of the rest of the European countries, which took a neutral stance on the whole issue. ${ }^{261}$ However, they practically applied the terms of the conventions signed with the Italian government. This was obvious in the response of King George of Britain to the request submitted by the Ottoman sultan to stop the Italian invasion in the province. The British monarch then apologized, citing the inability of Britain to perform this role, and that the country would remain neutral. ${ }^{262}$ The position of Germany could be also classified as neutral, but with a note on what Germany was trying to achieve on the ground. Germany took the initiative at this stage, especially at the expense of Britain, in addition to trying to attract the largest number of countries to pursue a policy of peace. However, they were seeking to attain the maximum advantages in doing so. In sum, the German approach was new in modern European politics. It can be considered as a kind of political maneuvering that had been pioneered by Germany, which excelled in implementing it as the country succeeded in leading the situations during the dispute between the Italian and the Ottoman governments until the outbreak of war between them in Libya. Germany continued to assume these responsibilities toward the issue of Libya, and its neutrality led to it being asked by Italy to protect Italian interests against the Ottoman side. The same request was also made by the Ottoman Empire. Therefore, Germany took over the evacuation of the Ottoman from Tripoli using German ships. They eva-

260 Mīkhā'īl, al-'Ālāqāt al-injīlìzìyya al-lìbiyyā, p. 32.

261 Ibid.

262 Baghnī, 'Amr Sāêì, Wathīqā 376, "Mukhtārāt min maḥūọāt shu'bat al-wathā’iq wa al-makhțūṭāt bi markaz jihād al-lībīyyīn dịd al-ghazū al-ițālī”, Majallat al-wathā’iq wa almakhțūțāt, markaz jihād al-lībīyyīn ḍid al-ghazū al-ițālī, Ṭarābulis, p. 156. 
cuated people including soldiers, doctors and pharmacists who had decided to leave the country. The German consul Alfred Tilger was in charge of their evacuation. ${ }^{263} \mathrm{He}$ also mediated the transfer of the belongings and property of the Ottoman soldiers in Libya to Istanbul in 1913, with the German ship Olos securing the transfer of this baggage. ${ }^{264}$ The position of German public opinion did not differ from the position of the government; thus, when the Italian fleet visited the ports of the province of Tripoli, the German newspapers took a unified stance. They made clear their reservations about the move. ${ }^{265}$

Tripoli was a station for many German doctors who arrived there during varying periods of time, many of them having provided their services to the local residents. It is to be noted that during the Italian invasion of Libya, Germany sent a health mission there, in 1912. The German health mission in the province of Tripoli could be divided into two phases: The first deals with the German doctors who worked individually, with most of them having been travelers. The second phase included the mission sent by the German Red Cross to Libya in 1912. The doctors came to Tripoli individually and on an unofficial basis. They were also included in the category of travellers and geographic explorers. One of those was Gerhard Rohlfs, who did not have a medical degree because he had not completed his university education in Germany. Instead, he stopped his studies of medicine and decided to travel to a new country. Gerhard Rohlfs studied the health situation in the province of Tripoli and visited a number of hospitals in the east and south of the province in 1865 . He provided a lot of information in his writings in terms of organization and methods of treatment used in the country. The historical information indicates the presence of another German doctor who was responsible for the hospital in the city of Benghazi in the east of the province during the second half of the $19^{\text {th }}$ century. ${ }^{266}$ The doctor Gustav Nachtigal differed from his predecessors in that he had extensive experience in the region in general. He also studied the health situations in the province of Tripoli in terms of the spread of diseases, particularly those coming from central Africa carried by trade caravans. Moreover, he studied the customs, traditions and ways of indigenous medicine. ${ }^{267}$ Nachtigal had an opportunity to practice his profession and also wrote a book in which he addressed communicable diseases in the

263 Ghānim, al-Bi'thā al-' 'almānīyya ilā Lìbiyā, p. 25.

264 al-Sāhịil̄, Khālīl, "Wamaḍāt min al-wathā'iq al-'ūthmānīyyā ḥawl al-fatra al-'ūlā min al-jihād al-lībī”, Majallat al-shahīd, 3, markaz jihād al-lībīyyīn ḍid al-ghazū al-ițāî, Ṭarābulis, 1982, p. 295. 265 Yahyya, al-Maghrib al-kabìr, p. 713.

266 Ghānim, al-Bi'thā al-' 'almānīyya ilā Lìbiyā, p. 16.

267 al-Fandarī, Munīr (translator), Ṭabīb al-mahalla al-bilād al-tūnīsìyya fĩ mabayn 1863-1868 min khilāl rasā'il al-țabīb al- 'almānī Ghūstāf Nākhtīgāl, markaz al-nashir al-jāmi 'i, Tūnis, 2003, pp. 47-48. 
region. ${ }^{268}$ He pointed out which areas had a good climate and were suitable for a better quality of life. The book focused on the south of the province and referred to diseases including typhus, malaria, fever, and cholera, which were the main causes of death of many residents, in addition to smallpox and other diseases. ${ }^{269}$ Nachtigal referred to tuberculosis as the most serious common disease. ${ }^{270}$ He also described local methods of treatment, which tended to be unsuccessful, and referred to the belief of the local people that some diseases originated from al-Jinn (supernatural creatures) and could be prevented using amulets or hanging parts of animals to expel al-Jinn. ${ }^{271}$ Nachtigal provided his medical services to the local people. Here he was helped by his experience gained in both Algeria and Tunisia. He also benefited from the local healers who were not only men, but there were a number of older women who practiced the profession of indigenous treatment according to their experience. Nachtigal had noted that the modern medical knowledge has not yet reached these parts of the country. ${ }^{272} \mathrm{His}$ work intended to first help the local people to combat epidemic diseases and the second intention was to give a clear picture to the government in Germany about the existing epidemic diseases in the north and center of Africa. ${ }^{273}$ They benefited a lot from this information in establishing their colonies there.

In 1911, the first year of the Italian war in Libya, the German doctor Felix Tlhaber volunteered to work in Libya with the Turkish Red Crescent and he remained in Libya from November 1911 to January 1912. ${ }^{274}$ Tlhaber arrived in Libya and headed to al-Aziziyah, used by the mujāhidīn as a gathering point and a military center for their leadership. He referred to one lady, the widow of a German captain in the army who made Tlhaber an offer to establish a hospital in Libya. Tlhaber found the health situation to be very bad in the country, and this prompted him to send a telegram to Berlin urging them to prepare a German medical clinic to

268 Nachtigal, Gustav, Sahara und Sudan, 3 vols., Berlin, Leipzig, Weltgeist-Bücher VerlagsGesellschaft m.b.h., 1879-1889.

269 See on the cholera disease in Tripoli, Tripoli, cadavres de cholériques [Image fixe]: [photographie de presse] [Agence Rol], Gallica, BNF Paris, [Novembre 1911], Reference 17336. And see also Tripoli, cadavres de cholériques [Image fixe]: [photographie de presse], [Agence Rol] Publication: [Novembre 1911], Refererence 17321. See as well on the same issue, Tripoli, cadavres de cholériques [Image fixe]: [photographie de presse]/[Agence Rol] Publication: [Novembre 1911] Idem, Reference 17314.

270 Ghānim, al-Bi'thā al-' almānīyya ilā Lībiyā, pp. 19-20.

271 Nachtigal, Sahara und Sudan, pp. 144, 147, 158.

272 Ghānim, al-Bi'thā al- 'almānīyya ilā Lìbiyā, p. 22.

273 Nākhtīgāl, al-Saḥrā’ wa bilād al-Sūdān, p. 213, 215.

274 Ghānim (translator), Taqārīr bi that al-ṣalīb al-aḥmar al-'almānī, p. 9. 
provide emergency aid to the people in Libya. He made great efforts to win the approval of the German authorities. This stage came within the framework of efforts by the German government to provide medical assistance specifically to the Libyan victims of the Italian war, as well as to provide treatment for the many common diseases in the country. The Italian attack on Tripoli had reverberated strongly in Germany and there was great sympathy with the people of the country, as the news presented the inhumane behavior of the Italian forces in Libya, which found stiff opposition from the German public opinion. The German authorities submitted a request to the Italians to provide such assistance, but the offer was rejected..$^{275}$ At the same time, another request was submitted to the Ottoman authorities, who welcomed the idea and the Ottoman Red Crescent started to be involved in providing help to the local people in Libya at this critical time. ${ }^{276}$ The timing of the proposal to provide financial aid was at Christmas in Germany, a period of celebrations, and therefore it was not possible to collect the amount of money necessary to prepare the medical mission and send it to Libya. On the other hand, the German Red Cross was unable to provide this amount of money. Thus, an appeal was announced to collect donations from the people; however, they were not sufficient to cover the expenses of the mission. German officials tried to overcome this financial problem. ${ }^{277}$ The idea of sending a health mission prompted a number of Germans working in the field of trade and industry, in addition to bankers, to form a special committee taking upon itself the responsibility of financing and supporting the health mission to Libya. ${ }^{278}$ Due to the concerted efforts of many Germans, they succeeded in equipping, the mission, which included three doctors, including Dr. Goebel, who was the chef of the mission, Dr. Fritz, and Dr. Schütze, three medical students, twelve nurses, ${ }^{279}$ a chemical doctor, electricity technician and a mechanical worker, and it was noted that they came from different cities. ${ }^{280}$ After the group completed their preparations they

275 Ibid., p. 17.

276 Ibid.

277 Ibid.

278 Central-Komitee der Deutschen Vereine vom Roten Kreuz (eds.), Beiträge zur Kriegsheilkunde. Aus den Hilfsunternehmungen der Deutschen Vereine vom Roten Kreuz während des ItalienischTürkischen Feldzuges 1912 und des Balkankrieges 1912/13, p. 1.; Kimmle, "Die Hilfsexpeditionen des Deutschen Roten Kreuzes nach Tripolitanien (1912) und nach dem Balkan (1912 und 1913)”, in Beiträge zur Kriegsheilkunde.

279 al-Barīkī, 'Abd al-Raḥmān 'Umar, "al-Ṭib al-sha 'bi wa daūr al-ba 'thāt khilāl fatrat al-jihād”, Majallat al-shahīd, 10, markaz jihād al-lībīyyīn li-l-dirāsāt al-tārīkhiyya, Ṭarābulis, 1989, p. 140.

280 Central-Komitee der Deutschen Vereine vom Roten Kreuz (eds.), Beiträge zur Kriegsheilkunde, p. 1. 
started their journey on a ship called Pera from Hamburg on January $11^{\text {th }}, 1912^{281}$ toward the port of Ben Guerdane, which was located on the Libyan-Tunisian border. 300 camels and twelve wagons were rented to transport the luggage and materials to Gharyan, where they decided to establishthe medical center of the mission; the mission had been fully equipped with equipment, medical devices, food, medicines and other items. The mission and the establishment of the hospital were directed mainly to provide the necessary services for people in the war zones and equipped according to the pattern of military missions. The hospital's function was not limited to this, but also took care of Libyan patients suffering from chronic diseases like typhoid, malaria, lung diseases and other diseases prevalent in the country at that time. The German doctors spared no effort in helping the local people, according to reports from those involved in the hospital, about 1.000 patients were treated, ${ }^{282}$ the diseases were also mentioned as follows: 43 patients with skin diseases, about 122 suffering from esoteric diseases, and 750 suffering from injuries or different diseases. ${ }^{283}$ Despite the seriousness of these diseases, they were treated by the German doctors, some of whom also became infected. Dr. Schütze and two of his assistants died. All were buried in Gharyan. ${ }^{284}$ It could be argued that the German mission provided great services to the Libyans in spite of the period of time they spent in the country, which was relatively short. Moreover, the results of their scientific research were very important in terms of assessing the situation and identifying the communicable diseases and indigenous treatments methods and medicine. Most important of all was the moral support provided by the Germans to the people of the country in a critical period. This positive German position was acknowledged by the international community and became a feature of the German policies adopted during the First World War. ${ }^{285}$

281 Ibid., p. 2.

282 Ibid., p. 10.

283 Ghānim, (Translator), Taqūrīr bi that al-ṣalīb al-ahmar al- 'almānī, pp. 19, 22, 25

284 al-Barīkì, "al-Tiib al-sha'bi”, p. 140.

285 Ghānim, al-Bi'thā al-'almānìyya ilā Lìbiyā, p. 22. 